\title{
Pekka Toivanen
}

\section{Robert ap Huw -käsikirjoitus ja transkription ongelma}

\section{Johdanto}

Viime aikojen myyvimpiin ja eniten kiinnostusta herättäneisiin trendeihin on kuulunut keskiaikainen kulttuuri sen eri muodoissaan ja lajeissaan. Levymyyntilistojen kärkisijoista ovat tasavahvasti rockartistien ja -yhtyeitten ohella kamppailleet gregoriaanista kirkkolaulua tai Hildegard von Bingenin musiikkia sisältävät äänitteet, joko "autenttisina" tai "cross-over" versioina. Samanaikaisesti keskiaikaseurat eri puolilla Suomea ja muuta maailmaa järjestävät esitelmätilaisuuksia, ajan henkeen sovitettuja päivällisiä, turnajaisia sekä tutustumismatkoja keskiaikaisiin kohteisiin. Rooli- ja tietokonepeleissä tapaamme kuningas Arthurin, maagikko Merlinin ja monia muita menneisyyden hahmoja. Keskiaika tuntuu olevan "in", tosin hyvin valikoidusti. Onko kysymyksessä todellinen kiinnostus ja halu tietää, mitä maanosassamme on ennen 1400-luvun puoltaväliä tapahtunut, vaiko pelkästään romantiikasta tutun eskapismin uusin versio, jota markkinavoimat osaavat hyödyntää? Objektiivisen vastauksen etsimisyritykset voivat olla sinänsä mielenkiintoisia mutta käytännössä hyödyttömiä, sillä asiakkaanhan sanotaan olevan aina oikeassa.

Mitä keskiaikaisen musiikin tutkimukseen tulee, on painopiste perinteisesti ollut vokaalimusiikin puolella johtuen osittain siitä, että laulettua materiaalia on kirjoitetussa muodossa säilynyt selvästi enemmän kuin soittimille tarkoitettua. Tietomme keskiajan soitinmusiikista ovat muutenkin hyvin puutteelliset. Ajalta ennen vuotta 1000 ei ole olemassa juuri minkäänlaista informaatiota soitinmusiikista ja sen käyttöyhteyksistä, itse musiikista puhumattakaan. Virallinen asennoituminen soittimiin ja niiden käyttäjiin oli keskiajalla hyvin kielteinen. Roomalainen filosofi Boethius (n. 480-524), jonka ajatuksia katolinen kirkko hyvin hanakasti käytti ja virallisissa musiikkiestetiikkanäkemyksissään sovelsi, oli vakaasti sitä mieltä, että instrumentalistit edustivat universaalisessa musiikillisessa hierarkiassa ehdottomasti alinta kastia ja toiminnallaan (soittamalla instrumentteja) 
saattoivat asettaa sielunsa ikuisen kadotuksen vaaraan. ${ }^{1}$

Yleisesti ottaen puhtaasti soittimille tarkoitettua musiikkia löytyy keskiajalta vähän. Suurin osa varsinkin moniäänisistä instrumentaalikappaleista oli soitinversioita vokaalimusiikista. Varhaisimmat kirjoitetut soitinkappaleet oli tarkoitettu kosketinsoittimille, lähinnä uruille. ${ }^{2}$ Huomattava keskiaikainen soitinmusiikin kokoelma on italialainen Faenza Codex (1410/1420), joka sisältää pääasiassa trecento-säveltäjien madrigaalien ja ballatojen kosketinsoitinversioita. Muuten keskiajan soitinmusiikki käsitti etupäässä joko yksiäänisiä tanssikappaleita tai soitinhoketuksia, joille ei notaatiossa oltu määritelty mitään kiinteää soitinkokoonpanoa. Joitakin tanssikappaleita on säilynyt mm. kokoelmassa 'Chansonnier du Roi' nimillä "Ductia", "Stantipes", "Estampida" jne.

Yleensäkin keskiajan yksiäänisessä soitinmusiikissa improvisoinnin osuus on ollut suurta, ja koska musiikkia on opittu ja levitetty kuulonvaraisen välittymisprosessin kautta, on valitettavan paljon jäänyt merkitsemättä muistiin ja siten tutkimuksen ulkopuolelle. Tätä taustaa vasten ajatellen onkin hivenen paradoksaalista, että eräs hyvin merkittävä, pääosin keskiajalta peräisin olevaa soolosoitinmusiikkia sisältävä käsikirjoitus on tähänastisissa tutkimuksissa jäänyt varsin vähälle huomiolle. Ja niissäkin tähän asti harvoissa asianomaista käsikirjoitusta ja sen musiikkia käsittävissä artikkeleissa ja tutkimuksissa, joihin olen tutustunut, vain neljässä ${ }^{3}$ on tähän mennessä pyritty selvittämään jotain myös sen musiikkikulttuurin olemuksesta, jonka lähes ainoa säilynyt kirjallinen dokumentti tämä käsikirjoitus on.

British Museumissa vuosina 1841-1845 tehtyjen käsikirjoituslisäysten luettelossa (the Catalogue of Additions to the Manuscripts in the British Museum in the year MDCCCXLI - MDCCCXLV) on luettavissa seuraava kuvaus:

Musica neu Berroriaeth, the Music of the Britons, as settled by a congress, or meeting of masters of music, by order of Gryffyd ap Cynan, Prince of Wales, about A.D. 1100; transcribed by Robert ap Huw of Bodwigan, Anglesea; temp. Car. I., from the original, by William Penllyn, a harper who lived in the reign of Henry VIII. Prefixed to, and at the end of the volume, in the handwriting of Lewis Morris, are various extracts from MSS. on the subject of Welsh music; with a copy of the Commission of Queen Elizabeth to the Counsel of Wales, for the admission of the the competent persons to be minstrels, dat. 23 Oct., 1567, and a drawing of the silver harp at

\footnotetext{
${ }^{1}$ Keskiaikaisen käsityksen mukaisesti musiikkia oli kolmessa "kerroksessa". Ylimpänä 'Musica mundana'; sfäärien harmonia (inhimillisellä tasolla musiikkifilosofit ja tieteilijät), keskellä 'Musica humana'; ihmisäänin toteutettu musiikki (lähinnä liturginen laulu) ja alimpana 'Musica instrumentalis'; soitinmusiikki, jonka katsottiin liiaksi perustuvan intuitioon suhteessa uskontoon ja tieteeseen. Ks. tarkemmin esim. Ling 1983: 94-97.

${ }^{2}$ Ensimmäiset säilyneet urkutabulatuurit ovat peräisin Englannista (Robertsbridge Codex 1325), ja ne sisälsivät mm. Philippe de Vitryn kolmiäänisiä motetteja tabuloituina kosketinsoittimille.

${ }^{3}$ Peter Crossley-Holland 1942; Thurston Dart 1968; Paul Whittaker 1974 ; Claire Polin 1982.
} 
Mostyn, in 1748, bestowed on the chief harper. Small folio. [14905] ${ }^{4}$

Ylläoleva esittelyteksti kuuluu käsikirjoitukselle, jonka virallinen luettelokoodi on BM.Add. MS $14905,{ }^{5}$ mutta joka tunnetaan musiikin tutkijoiden keskuudessa paremmin nimellä 'Robert ap Huw -käsikirjoitus' (tästä eteenpäin 'ap Huw MS'). Esittelytekstin mukaan kyseinen käsikirjoitus sisältäisi musiikkia, joka perustuisi Walesin prinssi Gryffyd (Gryffudd) ap Cynanin ${ }^{6}$ noin vuonna 1100 koollekutsuman mestarimuusikkojen kokouksen laatimiin päätöksiin.

Tämä käsikirjoitus on parin viimeksikuluneen vuosisadan aikana kiehtonut lukuisia ihmisiä, niin muusikoita kuin tutkijoitakin ympäri maailmaa. Sitä on lähestytty hyvin erilaisista näkökulmista käsin; milloin (kansallis)romanttisten ajatusten siivittämin mielikuvin, milloin tonaalisen musiikin ja sen analyysimenetelmien kautta. Toisissa yhteyksissä käsikirjoituksen sisältämä musiikki on ymmärretty jopa druidistista, muinaiskelttiläistä alkuperää olevaksi; tähän on epäilemättä vaikuttanut käsikirjoituksen kansilehdellä oleva maininta: " ... supposed to have been handed down to us from the British Druids. ${ }^{77}$ Viimeaikaisten tutkimusten mukaan ap Huw MS:n musiikki mitä ilmeisimmin sijoittuisi vasta myöhemmälle keskiajalle, suurin piirtein aikavälille 1270-1450. ${ }^{8}$

Paleografisesta näkökulmasta tarkasteltuna ap Huw MS koostuu kahdesta kerroksesta. Yhtäältä se sisältää 1600-luvun alkupuolella koottua materiaalia, jonka kirjoitustyöstä vastasi Robert ap Huw itse. Toisen kerrostuman muodostaa Lewis Morrisin (1701-1765) ja hänen veljensä Richard Morrisin (? - 1799) 1700luvun alkupuolella eri lähteistä kopioimat tekstit. Mainitut kaksi kerrostumaa erottuvat toisistaan $\mathrm{mm}$. erilaisten paperityyppien ja erilaisten käsialatyylien kautta. Käsikirjoitus oli joutunut Lewis Morrisin haltuun vuoden 1738 tienoilla, ja alkulehdiltä [i] käy ilmi, että se kuului hänelle vielä v. 1742. Hänen kuoltuaan se siirtyi Richard Morrisin haltuun, ja sittemmin Lontoon "Welsh Schoolin" omistukseen. Vuonna 1844 käsikirjoitus päätyi British Museumin (sittemmin British Libraryn) kokoelmiin saaden luettelonumeron Add. MS 14905. Käsikirjoituksen paleografiaa on tutkinut ainakin Claire Polin (Polin 1979), ja myöhemmin tarkennuksia vastaavasta näkökulmasta on tehnyt mm. Stephen Rees (Rees 1995).

\footnotetext{
4 "The Robert ap Huw Manuscript"; facsimilepainos (toim. Wyn Thomas, 1986); johdanto.

${ }^{5}$ British Museum Additional Manuscript 14905.

${ }^{6}$ Gryffudd ap Cynan (n. 1055 - 1137) oli Gwyneddin (pohjois-Wales) ruhtinas 1100-luvun alkupuolella. Hänen sanotaan tuoneen Irlannista (hän oli äitinsä puolelta irlantilainen) parhaat muusikot uudistamaan Walesin bardisen taiteen, minkä vuoksi häntä pidettiin Walesin musiikin epävirallisena suojelushahmona. Hänen nimiinsä laitettu 'Gryffudd ap Cynanin julistus' sisältää ohjeita ja säännöksiä bardisesta taiteesta, mutta on todennäköisimmin peräisin 1500-luvun alkupuolelta. Ks. tarkemmin Thomas 1968.

${ }^{7}$ Kansilehden teksti, sellaisena kuin se tunnetaan, on Lewis Morrisin käsialaa 1700-luvulta.

${ }^{8}$ Ks. Crossley-Holland, 1995.
} 
Musiikista suurimman osan oli siis merkinnyt muistiin Angleseyn saarelta, Bodwiganin kylästä kotoisin ollut harpisti Robert ap Huw (n. 1580 - n. 1658). ${ }^{9}$ Paitsi musiikkia, on Robert ap Huw merkinnyt käsikirjoitukseen ohjeita harpun virittämisestä, erilaisista asteikoista, soittotavoista sekä ilmoittanut omakätisesti olevansa vastuussa käsikirjoituksen laatimisesta.

Ap Huw MS sisältää siis pääasiassa harpulle tarkoitettua musiikkia, joka on merkitty muistiin hyvin erikoisella tabulatuurinotaatiolla (kuva 1). Tämän alkuperäisen merkintätavan siirtoyritykset modernille notaatiolle ovat johtaneet moniin toisiinsa nähden erilaisiin transkriptioversioihin. ${ }^{10}$

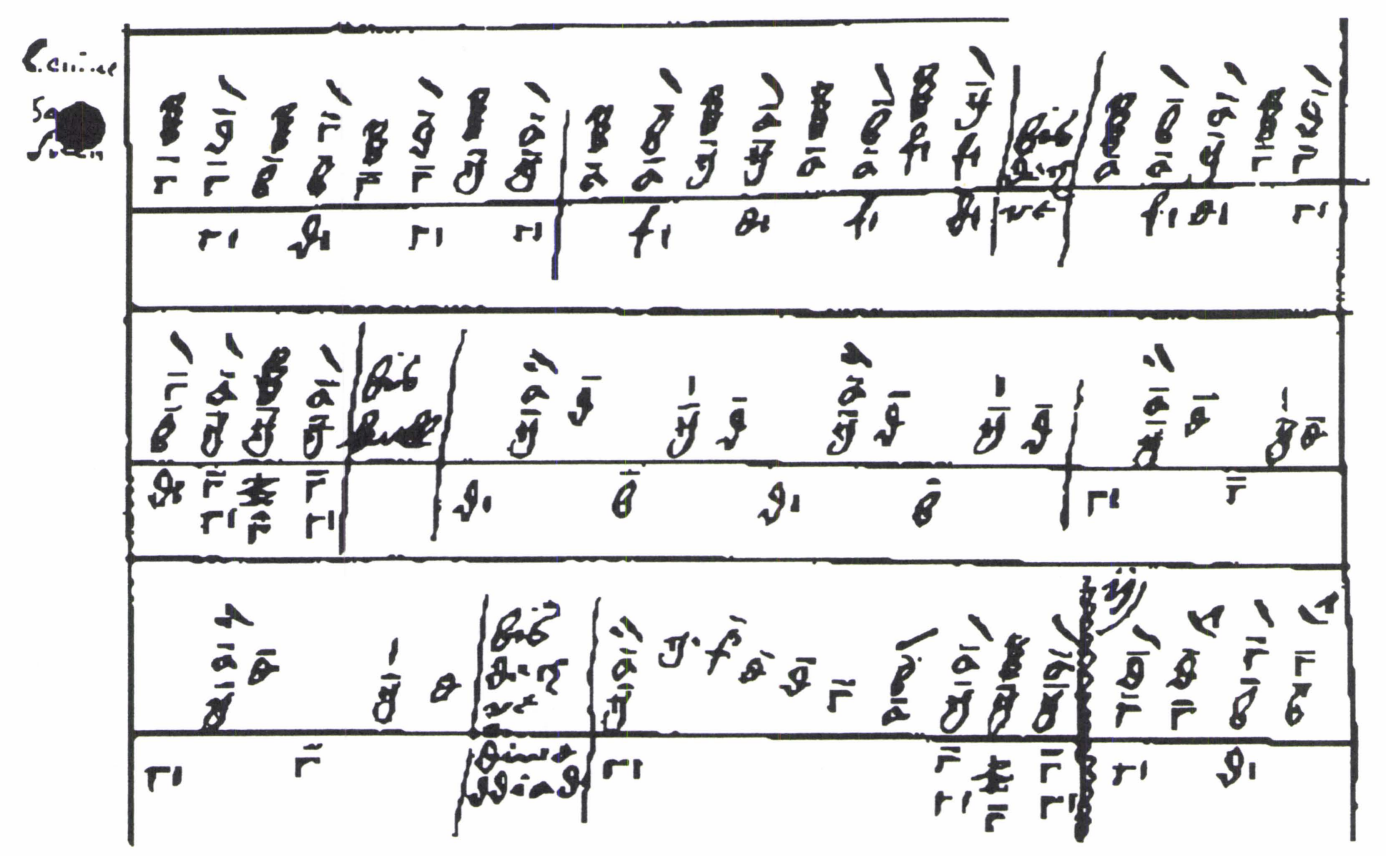

Kuva 1. "Caniad San Silin" (Ap Huw MS, s. 69); ensimmäinen 'cainc' (alkumelodia) ja sitä seuraava 'diwedd' eli lopuke, joka toistuu eri 'caincien' jälkeen lähestulkoon samanlaisena. Kirjainmerkkien välissä oleva poikkiviiva erottaa "ylemmällä" ja "alemmalla" kädellä soitettavat osuudet toisistaan. Vaakasuorat poikkiviivat, pisteet ja numeroindeksit kirjainmerkkien yhteydessä ilmaisevat oktaavialoja, muut merkit (esimerkiksi ylös- ja alaspäiset vinoviivat) soittotapoja.

\footnotetext{
${ }^{9}$ Käsikirjoituksen sivut 23 - 34 Robert ap Huw oli kopioinut William Penllynin kirjasta. Penllyn, joka ilmeisesti oli ap Huw'n opettaja (Polin, 1982) tämän jossain elämän vaiheessa, oli ilmeisesti saanut mestaribardin ('pencerdd' eli 'musiikin päällikkö') arvonimen Caerwysin eisteddfodissa v. 1567 (G. Thomas, 1968). Robert ap Huw'n elämänvaiheita ovat tutkineet mm. Dafydd Wyn William (William 1974) ja Nia Powell (Powell 1995).

${ }^{10}$ Ks. mm. Dolmetsch, 1937; Ellis 1980 ja 1991; Polin, 1982.
} 
Näiden rekonstruktioiden suurimpana puutteena ovat olleet rekonstruktiot itse, sillä niiden sisältämä informaatio edustaa pääsääntöisesti toisen asteen kirjallista käännöstä siitä traditiosta, jonka ensimmäistä kirjallisen käännöksen astetta edusti Robert ap Huw. Niissä editioissa näkyy mielestäni ajallemme (edelleen) tyypillinen käsitys, jonka mukaan vanha musiikki ei esityksellisesti (tai muuten) ole lähestyttävissä, ellei sitä ensin editoida uudelleen esimerkiksi sellaisen transkription muodossa, jota nykypäivän ihminen ymmärtää. Henkilökohtaisen näkemykseni mukaan pyrkimys selittää alunperin kuulonvaraisesti välittynyttä ja Robert ap Huw'n käden kautta tabulatuuriformaattiin päätynyttä vanhan tyylin walesilaista harppumusiikkia ('cerdd dant') ${ }^{11}$ nykyaikaisen nuottikirjoituksen avulla onkin perustavaa laatua oleva tutkimuksellinen lähtökohtavirhe. Tämän artikkelin eräs pääfunktio on löytää perusteluja edellä oleville väittämilleni.

\section{Traditio ja transmissio}

Bruno Nettlin mukaan etnomusikologian tutkijoille eräs luonteenomainen piirre on heidän kiinnostuksensa erilaisiin prosesseihin. Kulttuureissa tapahtuvat erilaiset muutokset - joko historiallisten tapahtumien rohkaisemina tai pakottamina - ovat etnomusikologialle ominaisia tarkastelun kohteita. Näihin muutoksiin vaikuttavat myös tapahtumat musiikissa, tyyleissä, rakenteissa, yksittäisissä kappaleissa tai lauluissa. Painopiste prosesseja koskien on teoreettinen mm. siksi, että äänitteet puuttuvat. Etnomusikologit ovat paljastaneet jotain oletettujen prosessien sisällöistä (ts. sellaisten tapahtumien, jotka ovat tapahtuneet pitkällä aikavälillä), ei niinkään tarkasti määrätyistä tapahtumista tarkkaan määrättynä ajankohtana. Niinpä traditiossa säilynyt yksittäinen musiikkikappale ei ole aina välttämättä jonkun nimetyn tai nimeämättömän säveltäjän alkuperäinen, muuttumaton luomus. Kysymyksessä saattaa ennemminkin olla lukuisia, pitkällä aikavälillä tapahtuneita (melodisia, rytmisiä jne.) muutoksia sisältävä versio jostakin ajallisesti paljon aikaisemmin luodusta sävelmästä, ${ }^{12}$ mutta jollaista alkuperäistä ei ole enää olemassa tai saatavissa (Nettl 1990, 297).

Traditioksi Nettl kutsuu kaikkea sitä, mikä pitää sisällään musiikin historiasta löydettävät erilaiset prosessit. Traditio on käsite, joka yhdistää toisaalta kulttuurin vakiintuneet elämän ja toiminnan muodot sekä viittauksen siihen, että tekijöidensä (ihmiset) perusluonteen mukaisesti näissä elämän ja toiminnan muodoissa tapahtuu pitkällä aikavälillä muutoksia. Transmissio on puolestaan tapa, jolla

\footnotetext{
${ }^{11}$ 'Cerdd' = 'taito', 'tan' = 'kieli'. Vanhan tyylin walesilaisesta harppumusiikista käytetty kotoperäinen ilmaisu 'cerdd dant' tarkoittaa 'kielisoittimen tai kielen taitoa'. Samaa käsitettä on käytetty myös tarkoittamaan crwthin soittoa tai crwth-musiikkia. Bardiseen taiteeseen kuului 'cerdd dantin' ohella myös 'cerdd dafod'; niin ikään 'kielen taito', tarkoittaen tällä kertaa taitoa tehdä runoutta.

12 Toisessa yhteydessä artikkeliaan Nettl käyttää termiä "emoversio".
} 
traditiota siirretään. Traditiota ja transmissiota käytetään usein kollokviaalisesti ilmaisemaan kulttuurin (ja musiikin) kahta puolta - yhtäältä sen stabiilisuutta, toisaalta sen pyrkimystä muutokseen (ibid., 297).

Nettl huomauttaa olevan paljon kirjallisia pyrkimyksiä kasata kuulonvaraiset traditiot stereotyyppisten käyttäytymismallien piiriin. Tässä hän viittaa Leo Treitlerin erääseen artikkeliin ${ }^{13}$ ja hänen siinä esittämäänsä arvioon, jonka mukaan kuulonvaraisessa kulttuurissa sävellysprosessi johtaa runsaisiin samankaltaisuuksiin. Samankaltaisuus on kuitenkin eri asia kuin identtinen. Kuulonvaraisen tradition stabiilisuus olisi etnomusikologian piirissä yleisesti hyväksytty (ehkä tarkemmin sitä tiedostamatta) positiiviseksi arvoksi mm. siksi, että sen katsotaan olevan paras lähtökohta nykyajan tutkijalle historiallisia tyhjiöitä täytettäessä (ibid., 302).

Samassa yhteydessä Nettl korostaa etnomusikologin työn kahta puolta; toisaalta tutkijan omat havainnot ja käsitykset tutkimastaan kulttuurista ja sen musiikillisista todellisuuksista, toisaalta tutkimuskohteen edustajien omat näkemykset. (ibid., 302) Nettl ei kuitenkaan tuo esiin, tarkoittaako hän vastaavanlaista suhtautumista myös 'historiallisten tyhjiöiden' täyttämiseen pyrkivässä työssä. Aiempana hän painotti äänitteiden puutteesta johtuen työn teoreettista luonnetta ja kiinnostuksen kohdistumista yleisiin asioihin. Hän jättää tässä yhteydessä huomioimatta mm. eri aikakausina ja eri kulttuureissa käytetyt soittimet ja niiden tarjoamat idiomaattiset mahdollisuudet, sekä sen, että äänitekin kuvaa ainoastaan yhtä esitystulosta monesta mahdollisesta.

Transmissiomalliksi Nettl esittää nelirakennetta, jonka lähtökohtana on yksittäinen sävellys ja sen historia. Sen mukaisesti jokaisella sävellyksellä olisi vähintään neljänlaista historiaa, ja sen myötä neljää mahdollista transmissiotyyppiä:

Tyyppi I: kerran luotu sävellys pysyy jotakuinkin muuttumattomana transmissioprosessissa

Tyyppi II: $\quad$ sävellys siirtyy traditiossa saaden vain yhden version (tai muuttuen yhteen suuntaan) jatkaen siten elämäänsä erilaisena kuin alkuperäinen, mutta ilman lukuisia variantteja

Tyyppi III: transmissioprosessi tuottaa lukuisia variantteja, joista osa hylätään ja unohdetaan, toiset taas jäävät osaksi kulttuuria. Näistä jotkut vakiintuvat tiettyyn olomuotoon osan saadessa koko ajan uusia variantteja.

Tyyppi IV: periaatteessa III:n kaltainen, mutta joka transmissiossa tapahtuvaa muuntelua varten käyttää lainamateriaalia, jolla alkuperäisen sävellyksen kanssa on hyvin vähän tai ei lainkaan tekemistä. (Nettl 1990, 302.)

Kolme ensimmäistä transmissio/historiatyyppiä ovat puhtaammin, ilman ulkopuo-

13 "Homer and Gregory", 1974 ("Musical Quarterly", vol. LX, 333-372). 
lisia vaikutteita, kulttuurin sisäisistä tekijöistä lähteneitä kuin neljäs. Niiden kaikkien lähtökohtana voi olla siis pelkästään yksi sävellys. Tämä malli on tekijänsä mukaan hypoteettinen, spekulatiivinen ja äärimmilleen pelkistetty vaikkakin tunnemme esimerkkitapauksia ainakin kolmannesta ja neljännestä transmissiotyypistä. (ibid., 303.)

Yksittäisen sävellyksen transmissiotyypeistä Nettl spekuloi mahdollisuutta, josko kokonaisia traditioita tai repertoaareja voitaisiin luokitella vastaavasti. Hänen mukaansa jokaisessa repertoaarissa on ainakin osa sellaista materiaalia, joka voidaan sijoittaa edellämainittuihin sävellysten transmissioihin. Ongelmana on kuitenkin (länsimaisen) musiikillisen terminologian riittämättömyys geneettisesti toisiinsa sukulaisuussuhteessa olevien musiikillisten yksiköiden erottelussa (ibid., 304). Toisaalta, juuri tämän vuoksihan tarvitaan ja käytetään jokaisessa kulttuurissa omia termejä ja ilmaisuja luokittelussa ja erottelussa. Esimerkiksi cerdd dant -musiikin 'cyweireja' ${ }^{14}$ ei tulekaan ymmärtää ensisijaisesti duurien ja mollien kautta.

On kulttuureja, joissa sävellykset noudattavat määrättyjä kaavoja/malleja yhteisön identiteetin ylläpitämiseksi ja sen vahvistamiseksi (ibid., 304). Usein materiaali, joka ei tule tästä sanastosta, ei saa joko ymmärrystä tai hyväksyntää samalla tavoin kuin kieli ottaa uusia ilmauksia tai lainasanoja omakseen. Tämä perussanasto voidaan Nettlin mukaan korvata käsitteellä musiikin tyyli, kun taas sisältö on tarkoitettu kuvaamaan kaikkia niitä asioita, joiden kautta yksittäinen sävellys erottuu muista samaan repertoaariin kuuluvista sävellyksistä (varianteista, toisista samankaltaisista kappaleista jne.). On luonnollisesti paljon tapauksia, joissa musiikilliset sukulaisuussuhteet tunnistetaan niin esittäjien/säveltäjien kuin kuulijoidenkin toimesta. Intialainen raga siinä esiintyvine 'pakar'-tunnusmotiiveineen (joilla on kullakin oma tunnesisältönsä) on hyvä esimerkki tästä.

\section{Vanha musiikki ja kuulonvaraisuus}

Kuulonvaraisuutta erityisesti keskiajan eurooppalaisessa musiikissa tutkinut Leo Treitler näkee kuulonvaraisuuden tietomenetelmänä, joka vaikuttaa kaikkeen kirjoitettuun. Treitler käyttää artikkelissaan käsitettä "musiikkiekonomia". Musiikkiekonomia sisältää kaiken, mikä liittyy musiikin tuottamiseen sävellyksen kautta tai sen avulla. Treitlerin systeemiin kuuluu transmissio, joka voi toteutua joko esityksen, kirjoittamisen, painamisen tai elektronisen median avulla, sekä tuotoksen vastaanottaminen. Oraalisen ja kirjoitetun välinen suhde tai sekoitus on musiikkiekonomiassa tärkeä tutkimuksen osa-alue, jollei kyseessä ole puh-

14 'Cyweir' (kirjoitetaan myös 'cywair' tai 'kower') on cerdd dant -musiikkiin kuuluva, varsin monimerkityksellinen termi. Sen päämerkitys on 'viritys' tai 'asteikko', mutta se voi tarkoittaa myös 'konsonanssia' tai 'vahvaa tai vakiinnutettua sävelkorkeutta'. 
taasti jompikumpi, mikä ei käytännössä liene mahdollista. (Treitler 1990, 39.)

Perinteinen [länsimainen] lähestymistapa on ollut kirjallisen/kirjoitetun pohjalta. Sen mukaan musiikin oppiminen on [ollut] musiikillisten kohteiden/objektien oppimista, ei prosessien tai tapahtumien. Kirjoitetun informaation asema on korostunut länsimaisen musiikin historiassa ja sen tutkimuksessa. Tätä tukee myös yleisesti hyväksytty näkemys, jonka mukaan musiikin on oltava säilötty (tai se tulee säilöä) kirjallisessa muodossa ollakseen sävellettyä (ibid., 39). Säveltäminen ja kirjoittaminen mielletäänkin usein synonyymeiksi. ${ }^{15}$

Treitlerin näkemyksen mukaan joudumme suhteessa keskiaikaiseen musiikkiin ottamaan uuden tarkastelulähtökohdan, jossa tutkimme musiikillisia objekteja transmissiossa tai transmissioprosessissa. Esimerkiksi käsikirjoitustutkimus voisi lähteä epistemologisesta lähtökohdasta, jonka mukaan kokonaisprosessi (eli prosessi, jonka kautta jostakin tulee taidetta ja samalla siis pysyvää) alkaa jonkun tekemästä luomisesta ja/tai nuotinnoksesta, ja saavuttaa terminaationsa vasta jonkun yhteisön vastaanoton ja tulkinnan kautta (ibid., 39).

Monien mielestä siis vain kirjoitettu edustaa pysyvää, sävellysprosessin lopullista pistettä, minkä jälkeen kaikki tehtävissä oleva on tehty ja muutokset ovat korkeintaan minimaalisia, sikäli kuin niitä voi tai saa tehdä lainkaan. Sanonnat, kuten " ... jos Bach olisi tarkoittanut tähän jotain muuta, hän olisi kirjoittanut sen..." edustavat ehdottomuudessaan vahvaa luottamusta kirjoitetun/painetun symbolin voimaan ja siihen, että kyseessä on tekijänsä viimeinen sana, josta interpretaatioprosessi lähtee liikkeelle. Säveltäjä on saattanut työnsä päätökseen, ja ainakin perinteisessä länsimaisen taidemusiikin tutkimuksessa ja esityskäytännössä nuotinnos on se informaatioketjun osa, jonka sisältöä harvemmin kyseenalaistetaan. Esitystodellisuudessa nuotinnos toimii kirjallisena perustana lukuisille erilaisille soiville ja editoiduille versioille, joissa graafisia symboleja toki voidaan tulkita eri tavoin mutta niiden kirjoitettua asua ei olennaisesti muuteta eikä partituuriin lisätä tai siitä poisteta olennaisesti mitään. Harvemmin on käynyt niin, että nuotinnokseen johtanutta sävellys- tai transkriptioprosessia ja sen vaiheita tutkittaisiin tai problematisoitaisiin.

Robert ap Huw'n ja cerdd dant -musiikin tutkimisen kannalta edellä kuvatun kaltainen paradigma, jossa kirjoitettua [notaatiota] pidetään valmiina, loppuun asti vietynä sävellyksenä, on virheellinen. Oman käsitykseni mukaan ap huw MS on nimenomaisesti kuulonvaraisesti opitun ja välittyneen musiikkikulttuurin soivan todellisuuden eräs kirjalliseen muotoon saatettu interpretaatio. Robert ap Huw'n käyttämissä merkinnöissä on oltu erityisen tarkkoja vanhalle tyylille ilmeisen ominaisten idiomaattisten elementtien suhteen, mutta samanaikaisesti ignoroitu rytmisiä ja melodisia ilmaisullisia tekijöitä. Hän tuo esiin tabulatuurissaan bardisen cerdd dant - musiikin keski- ja syvärakenteita ('mesurau' eli mitat) ja niitäkin tarkkuudeltaan vaihtelevalla tavalla (monissa kappaleissa hän jättää

\footnotetext{
${ }^{15}$ Esim. "songwriter", "music written by ...". Ks. myös Finnegan, 1986.
} 
kokonaan kirjoittamatta joitakin 'cainceja' antaen niistä vain ylimalkaisia esitysohjeita), mikä myös osaltaan viittaa pyrkimykseen merkitä muistiin musiikillinen performanssi.

\section{Repertoaarin muutos ja transmissio}

Puhuttaessa repertoaarin tiheydestä voidaan sillä tarkoittaa sitä astetta tai määrää, mihin asti [repertoaarin] erillisten yksiköiden voidaan sanoa olevan samankaltaisia riippumatta siitä, ovatko ne geneettisesti sukulaisuussuhteessa toisiinsa vaiko ei? Otettakoon esimerkinomaisesti kaksi sävelmäperhettä a) ja b), joilla on sama (joko todellinen tai kuviteltu) "emosävelmä":

a) kehittää variantteja, muotoja jne, jotka muotoutuvat etäälle toisistaan; variantin ja sen lähimmän sukulaisen välillä ei juuri mitään yhteistä $=>$ tiheys vähäinen

b) variantit musiikillisesti lähellä toisiaan; samantyyppiset musiikilliset ratkaisut toistuvat, joissakin tapauksissa jopa samanlaisessa järjestyksessä. (Nettl 1990, 305). ${ }^{16}$

Tiiviyden ja/tai hajanaisuuden määrän arvioiminen on riippuvainen paitsi määrittelijästä myös kokijasta, sillä kulttuurin sisä- ja ulkopuoliset kokemukset voivat olla erilaisia. Tiiviys/hajanaisuus eivät Nettlin mukaan ole riippuvaisia repertoaarien yksittäisten kappaleiden määrästä: 1900-luvun taidemusiikkirepertoaari on määrältään suuri, mutta hajanainen, kun taas 1700-luvun italialainen oopperamusiikki määrältään vähäinen sisällöltään kiinteä (ibid., 305). Oman tutkimuskohteeni, cerdd dantin, repertoaari (ainakin sen säilynyt osa) on määrällisesti vähäinen mutta sisällöltään suurelta osin kiinteä. Havaintojeni mukaan siinä käytetyt musiikilliset ratkaisut ja variaatiotekniikat ovat, paitsi hyvin lähellä toisiaan, tunnistettavia sekä 1900-luvulla elävälle bardisen kulttuurin ulkopuoliselle tarkkailijalle ja ennen kaikkea kulttuurissa itsessään eläneille. Ulkopuolisen - oli hän sitten oman tai jonkun muun aikakauden edustaja - tarkkailijan pääsy mainitun kulttuurin sisälle on tietenkin riippuvainen hyvin monista asioista, kuten esimerkiksi asianomaisen pyrkimyksistä ymmärtää cerdd dantin sisäinen "mitä" ja "miksi".

Ohjelmiston kiinteyden rinnalla on syytä puhua historiallisesta kiinteydestä eli siitä nopeuden määrästä, jolla yksittäinen musiikkikappale tai repertoaari muuttuu. Nettlin termi tähän on muutoksen dynamiikka tai tradition dynamiikka, joka voi olla hyvinkin vaihtelevaa; joissakin olosuhteissa laulu muuttuu hyvinkin nopeasti, toisenlaisissa sama tai samankaltainen sävelmä vaatii kolminkertaisen

\footnotetext{
${ }^{16}$ Esim. ap Huw MS:n kaksi ensimmäistä 'cwlwm gytgerdd' esimerkkiä (s. 23), joissa molemmissa tiheys toisiinsa nähden on suuri.
} 
määrän aikaa muutokseen. Muutoksia nopeuttavat tai hidastavat olosuhteet koskevat tietenkin hyvin erilaisia väestömääriä kerrallaan (ibid., 306). Tämä osaltaan ehkä selittää, miksi vanhantyylinen harppumusiikki säilyi kauemmin Irlannissa kuin Walesissa, jossa vanhaan kelttiläiseen kulttuuriin kohdistuvat muutospaineet olivat mm. englantilaisten walesilaisia kohtaa harjoittaman politiikan takia suuremmat. ${ }^{17}$

Etnomusikologinen tutkimus on Nettlin mukaan osoittanut, että kirjoitettu kulttuuri säilyy kuulonvaraista paremmin ja kauemmin muuttumattomana. Toisin sanoen; sen muutosdynamiikka on heikompi, koska se pystyy säilyttämään aikaansaannoksensa tavalla, joka ei kuulonvaraiselle kulttuurille ole mahdollista. Kuulonvaraisen kulttuurin muutoksiin taas vaikuttavat usein monet puhtaasti inhimilliset tekijät, kuten huono muisti tai ihmiselle luonteenomainen voimakas tarve muunteluun (Nettl ibid., 306). Kun ajattelemme cerdd dantia kuulonvaraisesti välittyneenä ja omaksuttuna taidemusiikkikulttuurina, ja kun vielä huomioimme monien allekirjoittaman käsityksen taiteelle ominaisesta pyrkimyksestä pysyvyyteen (myytti taiteen itseisarvosta), voimme tätä vasten paremmin ymmärtää bardisen kulttuurin auringonlaskuvaiheessa esiin nostetut, ja kirjallisessa formaatissa taltioidut, vanhojen auktoriteettien joko myyttiset tai todelliset lausunnot. Mitä todennäköisimmin juuri huoli bardisen kulttuurin säilymisestä hengissä on osaselitys 'Gryffudd ap Cynanin julistukselle' sekä myös ap Huw käsikirjoitukselle.

Toisen, Nettlin näkemyksille vastakkaisen mielipiteen mukaan kuulonvaraisesti välittyvät kulttuurit muuttuvatkin sisällöltään hitaasti, koska niiden kulttuurisen kontekstin yksinkertaisuus tekee niistä sisäänpäinkääntyneitä, ja kirjalliset traditiot, sofistikoituneesta muistiinmerkitsemissysteemeistä (kuten notaatio) johtuen, muuttuvat nopeammin. Nettl viittaa muitten etnomusikologien (Herzog 1949, 1033 ja Hood 1959, 201) tutkimuksiin. Länsimaisen taidemusiikin sisälläkin muutoksia on tapahtunut vaihtelevalla nopeudella, useasta accelerandosta monenlaisiin tempo rubatoihin.

\section{Kuulonvaraisuus kirjoitetussa}

Treitlerin mukaan historiallisten oraalisten kulttuurien (tai sekakulttuurien kuulonvaraista osaa) sisältöä tutkittaessa lähestyminen tapahtuu kirjoitetun kautta, jolloin tutkimuksen kohteina voivat olla:

${ }^{17}$ Ks. "By the Queen" (ap Huw MS, [vi] - [vii]) tai G.Thomas (1968, 35-43). 
muistin konseptio ${ }^{18}$

improvisoinnin ja muuntelun konseptio

suunnitellun (kirjoitettu ja/tai ei-kirjoitettu) konseptio (Treitler 1990, 39.)

Edellämainitut ovat luonnollisesti tangeeraavia. Suunnitellun konseptio on vuorovaikutussuhteessa muistin konseptioon, joka taas korreloi esimerkiksi improvisoinnin ja muuntelun konseption kanssa.

Treitler hakee taustaa ja esimerkkitapauksen varhaiskeskiajan musiikista. Hän lähtee liikkeelle [eurooppalaisen] nuottikirjoituksen varhaisvaiheista 700-luvulta, karolingeista, joiden tavoitteena oli levittää kirjoitettua oppiaan ja siten lisätä vaikutusvaltaansa henkisen ajattelun alueella. Treitler näkee siis notaation alun tarkoitushakuisena, ei pitkän kehitysprosessin tuloksena. ${ }^{19}$ Oraalisessa kulttuurissa voidaan puhua ennemmin melodisista proseduureista ja sekvensseistä kuin kiinteistä muotorakenteista. Melodian rooli on rinnakkainen tekstin jaksottamiselle ääneen lukemista tai resitoimista varten (ibid. 39-43). Samantyyppisiin tuloksiin on päätynyt myös Christopher Page ${ }^{20}$ trubaduuri- ja truveerilauluja käsittelevässä tutkimuksessaan.

Missä määrin kuulonvaraisen kulttuurin olennaiset elementit ovat sitten luettavissa kirjoitetusta? Treitler antaa esimerkkeinä toistuvat mallit ja kuviot, sekvenssit, stereotyyppiset ilmaisut, määrätyt formulat, jotka ovat lähes aina käytössä ${ }^{21}$ ja määrätyt musiikillisen ilmaisun komponentit on vakiinnutettu. ${ }^{22} \mathrm{Ne}$ ovat keski- tai syvärakenteen osia, jotka edustavat tiettyä stabiilia reproduktiivisuutta musiikillisessa kudoksessa ja jossa pintatasolla eriasteinen muuntelu erottuu selkeästi (ibid., 43).

Määrätyt toistuvat esim. rakenteelliset elementit toimivat tapahtumaindikaattoreina. Ne rajoittavat säkeitä, antavat vakiokestoja osakokonaisuuksille jne. Cerdd dantissa rakenteellisuutta luovien elementtien, kuten mesuraut, diweddit ${ }^{23}$,

\footnotetext{
${ }^{18}$ Tekstin, tekstikaavojen, rakenteiden, melodiamotiivien yms. muistaminen.

${ }^{19}$ Treitlerin hypoteesin mukaan kreikkalaiset, bysanttilaiset ja hebrealaiset notaatiosysteemit eivät olleet kehitykseen vaikuttavina tekijöinä. Varhaiset latinalaiset systeemit eivät painota yksittäisiä intervalleja vaan joko yksittäisiä nuotteja tai nuottiryhmiä; poikkeuksia on, mm. "Musica enchriadis". Nuottikirjoituksen syntyminen vasta karolingien aikakaudella asettaa Treitlerin mukaan kyseenalaiseksi gregoriaanisen laulun yhtenäisyyden ajalta ennen 700-lukua.

${ }^{20}$ Ks. Page (1987; esim. sivut 14-17).

${ }^{21}$ Vrt. 'clymmau gytgerdd' (ap Huw MS, sivut 23-34).

${ }^{22}$ Esim. 'pedwar ar hugain mesurau cerdd dant' eli 'kielisoitinmusiikin 24 mittaa'. Nämä 'mitat' olivat kahden harmonisen muuttujan muodostamia ketjuja; eräänlaisia ostinatoja, joiden perustalle voitiin joko säveltää tai improvisoida musiikkia. Tästä eteenpäin käytän termejä 'mesur' (yksikkö) tai 'mesurau' (monikko). Ks. tarkemmin 'Gosteg yr halen'-esimerkki myöhemmin tässä artikkelissa.

23 'Lopuke'; ks. analyyttinen esimerkki kappaleesta 'Caniad San Silin'.
} 
cyweirdantien ja tyniadien ${ }^{24}$ vuorottelu, voidaan myös sanoa edustavan reproduktiivisuutta ja siten vakiintunutta musiikillista käytäntöä, joka voi olla joko kirjoitettua ja siitä opittua, tai suullista

Prosessi on additiivinen ja siinä muusikko toimii luovana tekijänä tekstirakenteen tai jonkun muun rakenteen puitteissa. Tämä edellyttää, että muusikko on perillä jaksottamisperiaatteista. Prosessi lisää syvä- ja keskirakenteeseen pintarakenteen ja voi joissakin tapauksissa muuttaa myös syvä- ja keskirakennetta. Jos cerdd dantin kohdalla ajattelemme syvärakenteellisina elementteinä mesuria ja caincia $^{25}$, jotka molemmat käsitykseni mukaan edustavat kuulonvaraisesti opittua ja vakiintunutta reproduktiivista rytmistä kehystä, voimme tässä nähdä yhden syyn tabulatuurinotaation rytmiseen epätarkkuuteen, ja siten Robert ap Huw'n joko tarkoituksellisesti tai tarkoituksetta tekemiin puutteellisiin merkintöihin.

Monissa tähänastisissa ap Huw -käsikirjoitusta käsittelevissä tutkimuksissa on huomionarvoista niissä esiintullut seikka, josta äskeisiin prosessiesimerkkeihin vedoten voitaisiin sanoa historiallista aikaperspektiiviä käytetyn bardisen musiikkikulttuurin kannalta väärään suuntaan, eli kohti nykyaikaa. Monissa tapauksissa ei siis haeta mahdollisia musiikillisia lähtökohtia tai "emotekstejä" menneisyydestä, tai edes Robert ap Huw' n omasta ajasta, vaan sellaisiksi otetaan cerdd dant musiikkia ajallisesti myöhemmät kirjalliset musiikkia tai musiikin teoriaa koskevat lähteet. Tällä tarkoitan joissakin tutkimuksissa esiintyviä pyrkimyksiä selittää harmoniaa sekä asteikkoja/virityksiä koskevia elementtejä tonaalista musiikkia ja funktionaalista harmoniaa käsittelevien kirjoitusten kautta. ${ }^{26}$ Ratkaisuja on pyritty siis hakemaan omaa aikaamme ja klassis-romanttista musiikkia lähempänä olevista lähteistä, ja niiden avulla koetettu selittää keskiaikaisessa cerdd dant musiikissa olevia ilmiöitä. Vaikka tarkoituksena olisikin ensisijaisesti tuottaa soitettavaa materiaalia oman aikamme harpisteille, käytetyt metodit muistuttavat mielestäni aivan liian paljon kansallisromantiikalle tyypillisiä keinoja saada oman kansan [musiikillinen] menneisyys näyttämään halutun kaltaiselta, joskus keinolla millä hyvänsä.

Treitler tuo artikkelissaan esiin musiikin generatiivisen systeemin. Sen mukaisesti musiikilliset toteutukset (sävellykset, esitykset) perustuvat tiettyjen syvärakenteellisten tekijöiden varaan, joiden pohjalta muusikko luo itse omat toteutuksensa. Tietty rakennuspalikkakompleksi (tai perusta) on vakio, muusikko "monistaa" niitä esityksen aikana koristellen ne hivenen toisistaan poikkeavasti mutta kuitenkin kulttuurille ja tyylille ominaisesta maalivarastosta. (Treitler; ibid, 43)

24 'Cyweirdant'= vahva kieli, konsonoiva elementti; 'tyniad' = heikko kieli, dissonoiva elementti.

${ }^{25}$ 'Cainc' = ydinmelodia (sananmukaisesti 'oksa'), joka rakentuu joko mesurin pohjalle tai vapaasti.

${ }^{26}$ Mm. Dolmetsch (1937), Ellis (1980 ja 1991), Polin (1982) ja jopa Whittaker (1974), joka muuten erittäin ansiokkaassa tutkimuksessaan kuitenkin kaipailee harmoniselle mollille ominaista korotettua johtosäveltä joihinkin kappaleisiin. Selkeästi menneisyyteen puolestaan hakeutuu Travis (1968), joka etsii musiikillisia juuria mm. muinaiskelttiläisten kiviristien ornamentiikasta. 
Ap Huw -käsikirjoituksen järjestyksessä toinen kappale "Gosteg yr halen" (kts. kuva2) toimii hyvänä esimerkkinä generatiivisen systeemin varaan rakentuvasta musiikillisesta toteutuksesta, kuten itse asiassa muutkin käsikirjoituksessa olevat gostegit ${ }^{27}$ ja cwlwmit. Siinä jokaisessa caincissa samanlaisena toistuva mesur ('mak y mwn byr') ja toisen mesurin (tai sen osan) varaan rakentuva diwedd ovat koko kappaleen muuttumattomana toistuva perusta. Jokaista caincia seuraa siis aina sama diwedd, ja kunkin caincin vakiona pysyvän mesurin päälle diskanttirekisteriin on tehty uusia, toisiinsa nähden erilaisia musiikillisia ratkaisuja, joiden voidaan katsoa edustavan pintarakenteessa tapahtuvaa muuntelua.

Muuntelu ei kuitenkaan ole sattumanvaraisuudelle rakentuvaa (joten tiettyä reproduktiivisuutta siinäkin on), ja systemaattisuuden vaikutelmaa lisää, että kussakin yksittäisessä caincissa käytetään yhtä melodis-rytmisen muuntelun periaatetta kerrallaan, jota sitten toistetaan eri transpositioissa. Musiikillisilta ratkaisuiltaan gosteg onkin hyvin lähellä sellaisia keski- ja renessanssiajan sävellystyyppejä (tai paremminkin generatiivisia systeemejä; kaavoja) kuin 'dump', 'romanesca' tai 'passamezzo antico' ${ }^{28}$ Rakenteellisesti gosteg muistuttaa puolestaan keskiaikaista 'estampieta'. ${ }^{29}$

27 'Gosteg' on Enid Robertsin (1982) mukaan rakennetyyppi, jossa 10-13 caincia on laitettu ketjuun, ja kunkin caincin jälkeen soitetaan vakiomuodossa toistuva diwedd. Siinä sovelletaan musiikkiin runouden erästä rakennekokonaisuutta, jossa sarja 'englynejä' (eräs bardisen runouden keskeisistä säkeistöllisistä rakenteista) liitetään toisiinsa, ja uusi englyn alkaa edellisen lopusta. Musiikissa gosteg on ensisijaisesti soitinsävellys ilman selkeää kytkentää sen suuremmin runonlausuntaan kuin lauluun.

${ }^{28}$ Esimerkiksi "Greensleeves" voi rakentua joko 'romanescan' tai 'passamezzo anticon' varaan.

29 'Estampie' on keskiaikainen soitinmusiikissa käytetty rakennetyyppi, jossa on vaihtuvien alkuosien ('pars') jälkeen samanlaisina toistuvat lopukkeet ('ouvert' ja 'clos'; avoin ja suljettu lopuke). Estampien juuret ovat löydettävissä gregoriaanisesta sekvenssistä ja maalliseen laulumusiikkiin kuuluvasta 'laista'. Lai oli bretagnelaiselle kulttuurille ominainen tyylilaji, jonka teksteissä käsiteltiin usein vanhoja kelttiläisiä sankariarkkityyppejä, kuten kuningas Arthuria tai Tristania. Ks. esim Page (1987, luku 3).

Mielenkiintoinen tähän sopiva yksityiskohta on 'Gosteg yr halenin' lopussa (ap Huw MS; 19) oleva maininta, jonka mukaan kyseistä kappaletta olisi soitettu seremoniamusiikkina kuningas Arthurin hovissa silloin, kun suola-astiaa kannettiin ruokapöytään (halen = suola). Kyseessä lienee joko 1300/1400-luvuilla herätettyyn Arthur-kulttiin (tuolloin syntyi runsaasti mm. Arthur-aiheista kirjallisuutta) kuuluva ilmiö, tai "Gryffudd ap Cynanin julistuksen" kaltainen vanhojen auktoriteettien esiinkutsu pelastamaan kuolemassa oleva bardinen kulttuuri. Robert ap Huw'n sanotaan kirjoittaneen käsikirjoituksensa vuonna 1613, ja tuolloin vanha 'cerdd dant' edustajineen oli jo suurelta osin lakannut olemasta. 

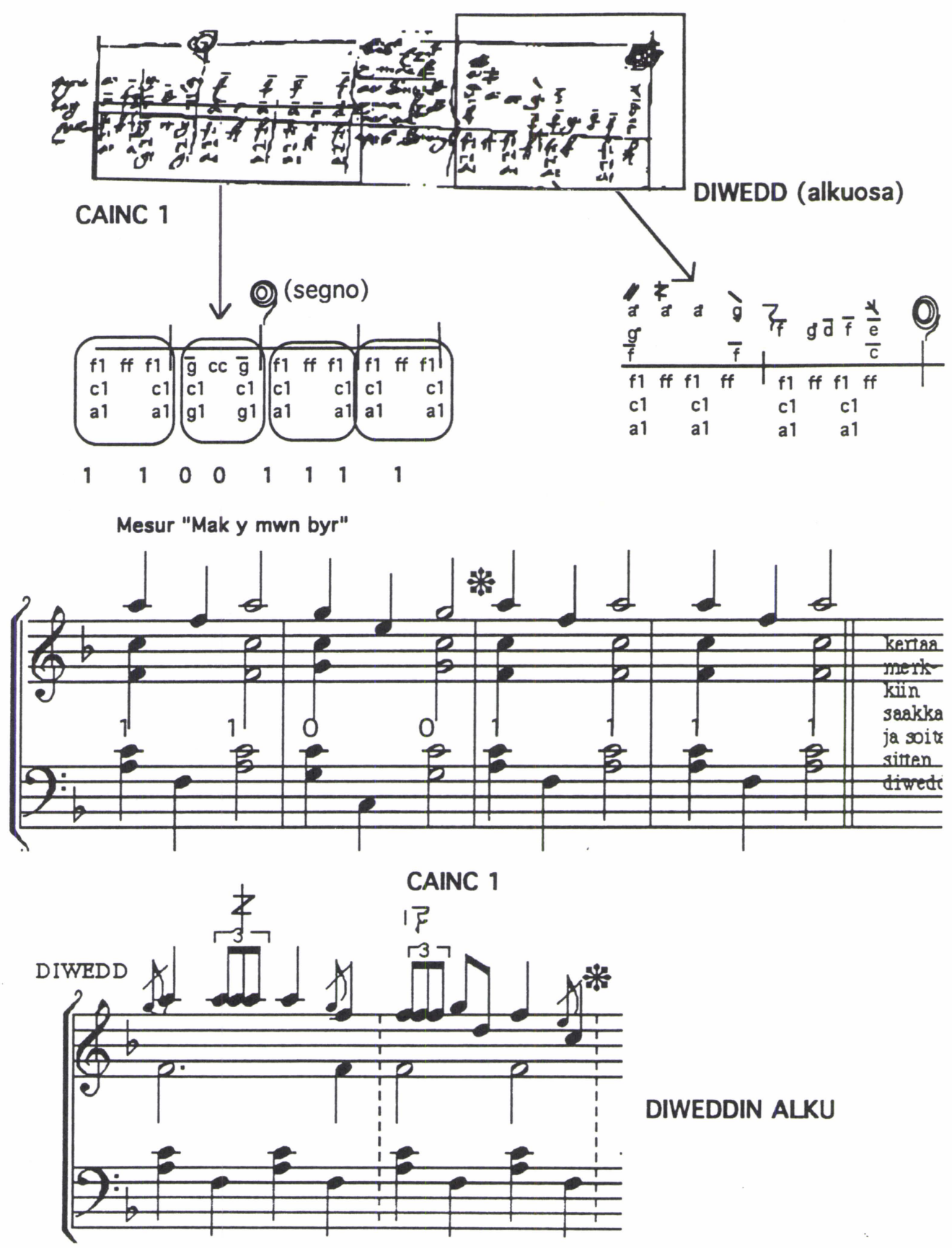

Kuva 2. 'Gosteg yr Halenissa' käytetty 'mesur' (Mak y mwn byr) erotettu alkuperäisestä tabulatuurikuvasta omakseen. Sen yhteydessä käytetty numerosarja (11 0011 11) on tämän mesurin oma "koodi", jonka avulla se on erotettavissa muista samoja numeroja, mutta toisenlaisessa järjestyksessä ja eri määrissä käyttävistä mesureista. Numerot 1 ja 0 viittaavat kahteen harmoniseen muuttujaan, joita cerdd dantissa ilmaistaan myös termeillä 'cyweirdant' ja 'tyniad'. 
Samantyyppisen generatiivisen systeemin voidaan sanoa koskevan myös cwlwmeja. Enid Robertsin mukaan (1982) cwlwm on a) 24 kertaa yhdessä mesurissa soitettava cainc, jossa diskantissa olevat "maalivaraston" ornamentit vaihtuvat joka kierroksella tai sitten b) 24 :ssä eri mesurissa muilta soittotavoiltaan (ornamentit jne.) samana toistuva cainc. Täysin erilaisen tabuloidun cwlwm -tyypin tarjoaa Iolo Morgannwg -käsikirjoitus, ${ }^{30}$ missä cwlwm ei ole kuin pieneltä osaltaan sidottu edellä kuvatun kaltaisiin rakenteisiin. ${ }^{31}$ On mahdollista, että Iolo-käsikirjoituksen sisältö on yritys kirjoittaa muistiin korkeampaan bardiseen tutkintoasteeseen kuulunut esitys.

Robert ap Huw -käsikirjoituksen gosteg- ja cwlwm-tyypit näyttäisivät kuitenkin olevan generatiivisilta systeemeiltään sen verran selkeitä, että tabulatuurimerkintöjen soveltaminen käytäntöön on tämän artikkelin kirjoittajan soittajaminän näkökulmasta melko helppoa. Pitkä variaatiosarja, joka perustuu yhden kerrallaan muuttuvan musiikillisen idean varaan, ja jonka ei esitystilanteessa ole tarvinnut mennä välttämättä siinä järjestyksessä, missä se on kirjoitettu, on cerdd dant -musiikissa toiminut luovan ja spontaanin (mutta "sääntöjen" puitteissa tapahtuvan) musiikin tekemisen kehyksenä. Näin selkeä tilanne ei ole käsikirjoituksen 'caniadien ${ }^{132}$ ja muiden ap Huw MS:n kompositiotyyppien osalta, ainakaan siinä muodossa kuin Robert ap Huw on ne kirjoittanut.

Päinvastoin kuin Nettl, Treitler edustaa siis näkemystä, jonka mukaan kuulonvarainen kulttuuri voi olla sääntöjen ja standardointien suhteen paljon tiukempi kuin kirjallinen. Nettlin mukaan kuulonvarainen kulttuuri on herkempi muutoksille kuin kirjallinen ja perusteiksi hän esittää mm. inhimillisistä tekijöistä (usein heikkouksista) johtuvat syyt. Treitler puolestaan näkee stereotypioita enemmän oraalisessa tai sellaisessa kulttuurissa, jolla on pitkä kuulonvaraisesti välittynyt perinne ennen siirtymistä kirjoitettuun (kursivointi tekijän).

\section{Cerdd dantin muut käsikirjoituslähteet}

Olen aiemmin viitannut walesilaisen bardisen kulttuurin olemassaolon viimeisissä vaiheissa tehtyihin kirjoituksiin, joissa henkiinjäämistaisteluun kutsuttiin avuksi entiset itsenäisen Walesin aikaiset ruhtinaat ja taiteen mahtimiehet. Peter Crossley-Hollandin tekemän erinomaisen vanhan harppumusiikin säveltäjiä

\footnotetext{
${ }^{30}$ BM. Add. MS 14970; tunnetaan myös nimellä Rhys Jones-käsikirjoitus; fragmentaarisena säilynyt toinen kirjallinen dokumentti 'cerdd dant -musiikista' (kopioitu Myvyrian Archaelogyn sivuille 1071 - 1082). Paul Whittaker on uusimmassa työssään (Whittaker 1995) tarkastellut Iolo MS:n sisältöä.

31 'Cwlwm bach yn y go gywairin' viimeinen cainc, ja sekin vain osittain.

32 'Caniad'; laulu, sävelmä. Enid Robertsin (Roberts 1966/1982) mukaan enemmän laulu- tai tekstisidonnainen kuin esim. gosteg; rakenteeltaan 13-17 x cainc. Ap Huw MS:n caniadit saattavat osittain olla transkriptioita laulun/resitoinnin säestyksistä.
} 
koskevan tutkimuksen (1995) mukaan Robert ap Huw -käsikirjoituksen musiikki olisi siis peräisin aikaväliltä n. 1270-n. 1450, kun itse käsikirjoitus on vasta vuodelta $1613 \cdot{ }^{33}$ Emme tiedä, oliko tätä musiikkia merkitty kirjalliseen muistiin aikavälillä n. 1450-1550.

Pitäkäämme kiinni ajatuksesta, että musiikki siihen kuuluvine elementteineen ja rakenteineen sïrtyi kuulonvaraisesti mestarilta kisällille 1500-luvun puoliväliin saakka, mitä todennäköisimmin vielä sen jälkeenkin, ehkä aina 1600-luvun puolelle. Musiikkia koskevaa säännöstöä oli käsikirjoitusmuodossa kuitenkin olemassa viimeistään 1500-luvulla (kuten "Dosbarth Gerdd Dannau"34 tai "Gryffudd ap Cynanin julistus"), mutta missään näissä ei ole nuotinnoksia tai muunkaanlaisia transkriptioversioita itse soitetuista sävelmistä.

"Dosparth Gerdd Dannaun" ensimmäisissä lauseissa viitataan eräisiin mestarimuusikoihin ja heidän kirjoituksiinsa:

Tämä on kirja instrumentaalimusiikin säilyttämiseksi, nimittäin harpun ja crwthin, kolmen Walesin ruhtinaskunnan alueella ja mikä syntyi neljän päämuusikon toiveesta, jotka yksimielisesti nuotinsivat (kirjoittivat) musiikkia pitääkseen sen paremmin mielessä, soittaakseen sitä oikein ja analysoidakseen sitä. Nämä neljä päällikköä olivat Allon, Rhydderch Foel, Matholwch Irlantilainen ja Olaf Soittoniekka. Kuulijoina olivat Henry Gyfourhyd ja Carsi Harpunsoittaja monien muiden neuvoillaan ja tiedoillaan auttaneiden ohella. (Ap Huw MS, 5-7.)

$\mathrm{Ne}$, jotka "kirjoittivat musiikkia" - mitä he siis kirjoittivat? Notaatiota vaiko säännöstöjä, jotka koskivat mittoja ja soittotapoja? Olivatko näissä kirjoituksissa mainitut musiikin 24 mesuria säilyneet muuttumattomina, stereotyyppisinä rakenteellisina ratkaisuina ja osana suullista traditiota 1200-luvun loppupuolelta 1500-luvulle saakka? Olivatko nämä ainoat virallisesti sallitut kahden [harmonisen] elementin muuttujayhdistelmät, ja olivatko ne kaikki olleet olemassa useamman vuosisadan ajan. Ryhdyttiinkö niitä sittemmin opettamaan ja muistamaan ulkoa, kirjoitettua tekstiä oppikirjana pitäen? Tähän mennessä en ole törmännyt minkäänlaisiin kirjoituksiin bardista kulttuuria ja cerdd dant -musiikkia koskien, joissa olisi korostettu luku- ja kirjoitustaidon merkitystä muistin kustannuksella. Kertomukset bardisen runouden ja musiikin oppimismetodeista sekä sokeiden vanhan tyylin harpunsoittajien suuresta määrästä eivät myöskään tue kirjallisen välittymisen, vaan ulkoa opittavien ja muistettavien rakenteiden aseman keskeistä osuutta.

\footnotetext{
${ }^{33}$ Paitsi 'Clymmau gytgerdd-osio' (sivut 23-34), jonka ap Huw siis kopioi William Penllynin kirjasta.

34 "Kielisoitinmusiikin luokittelu"; alkuperäinen on kadonnut, mutta kopioita (osittaisia) on löydettävissä eri käsikirjoituksista (mm. Panton 56, Peniarth 194 ja Havod 3). Lewis Morris on kirjoittanut siitä otteita ap Huw MS:n alkusivuille.
} 
On hyvin mahdollista, että eri musiikinlajeja opittiin muistamaan mesurien avulla. Kun kaikki 24 mesuria ${ }^{35}$ oli bardisen koulutusjakson aikana saatu vakiinnutettua harpistin ja 'crotherin' (crwthin soittaja) muistiin, toimivat ne, kuten on jo aiemmin todettu, rakennuspalikoina laadittaessa cainceja, gostegeja jne. Soittaja hahmotti ja jaksotti musiikkinsa niiden puitteissa, ja saattaa olla, että jos esitys syystä tai toisesta katkesi, heillä oli vaikeuksia jatkaa suoraan eteenpäin, vaan heidän piti aloittaa alusta. Ap Huw MS:n musiikkikappaleista, ja siinä, sekä muissa käsikirjoituksissa olevista kappalelistoista päätellen suhteellisen harvat mesurit olivat enemmälti käytössä. Olisiko niin, että cerdd dant -harpisteilla oli joitakin preferenssejä määrättyjä 'mesureja' kohtaan samalla tavoin kuin esim. turkkilaisessa musiikissa tiettyjen makamien tai usulien suhteen, vai oliko monimutkaisempien mesurien kohdalla tilanne se, että niitä oli sen verran hankala muistaa ja hahmottaa, että niiden käyttö jäi vähäiseksi. ${ }^{36}$

Näistä käsikirjoituksista (Panton, Peniarth, Havod etc.) voi myös päätellä, kuinka vaikeaa oraalisen kulttuurin elementtien siirtäminen kirjoitettuun muotoon on ollut. Virityksiä ja mittoja (vain kaksi asiaa mainitakseni) koskeva informaatio, eri käsikirjoituslähteitä toisiinsa verraten, on hyvin ristiriitaista ja vaikeasti tulkittavaa, mikä osaltaan on vaikeuttanut tutkittavan bardisen musiikkikulttuurin ja cerdd dantin elementtien ymmärtämistä. Tiedot ovat fragmentaarisia, usein toisensa pois sulkevia ja täynnä vertauskuvallisia ilmaisuja, joiden sisältö (tai sisällöt) ovat voineet hyvinkin olla tuttuja cerdd dant -musiikin omassa kontekstissaan sisäistäneille, mutta ei välttämättä suullisen informaation vastaanottajille.

Monessa yhteydessä on tuotu esille niitä ongelmia, joita syntyy silloin, kun (musiikki)kulttuurista kirjoittava ei ole riittävästi perillä kuvaamansa kulttuurin sisällöstä. ${ }^{37}$ Bangorissa heinäkuussa 1995 järjestetyssä 'Robert ap Huw -symposiumissa' tuli keskusteluissa esille, että 1500-1600-lukujen taitteessa Walesissa oli joitakin renessanssihenkisiä aatelisia, ${ }^{38}$ jotka "Il Cortegianon" innoittamina katsoivat asiakseen suojella vanhoja taiteita, mukaanlukien cerdd dant, uusien trendien hyökkäyksiltä, ja olivat ilmeisesti valmiita sietämään vanhan kulttuurin edustajilta ${ }^{39}$ melkein mitä tahansa. Ilmeisesti samanhenkisiä aatelisia oli Irlannissa vielä 1700-luvun alkupuolella, mikä saattaa osaltaan selittää, miksi mm. Carola-

\footnotetext{
${ }^{35}$ Luettelo mesureista ja niiden numeroyhdistelmistä on mm. ap Huw MS:n sivulla 107. Tarkemmin näitä ja niiden mahdollisia sovellutuksia on tutkinut mm. Travis (1968). Mielenkiintoinen hypoteesi mesurien ja kuuluisan "Kesäkaanonin" mahdollisista yhteyksistä löytyy Shai Burstynin artikkelissa "Gerald of Wales and the Sumer Canon" (1984).

${ }^{36}$ Analogia suhteessa mesurin käyttöön muistiyksikkönä löytyy mm. Erkki Pekkilän 'juoksuvalssianalyysista' (Pekkilä 1986; 208).

${ }^{37}$ Ks. esim Titon (1988; 10 - 14) tai Toivanen (1995).

${ }^{38}$ William Mostyn, joka oli avokätinen bardisen kulttuurin suosija; ehkä myös Panton- ja Peniarthkäsikirjoitusten tekijät.

${ }^{39}$ Ks. N. Powell (1995) ja hänen havaintonsa koskien Robert ap Huw'n käyntejä lain väärällä puolella.
} 
nin erikoista käytöstä siedettiin varsin pitkälle. ${ }^{40}$ Mutta oliko kirjoitettuun, mutta hajanaiseen muotoon saatettu bardisen kulttuurin tieto (monia muita syitä unohtamatta) samalla osa viimeistä voitelua koko kulttuurille? Vanha aatelisille kuulunut muusikkojen ylläpitojärjestelmä, jollainen viimeistään Hywel Ddan ajoista (900-luvun jälkipuoli) saakka oli ollut bardisen järjestelmän olemassaolon edellytys, lakkasi 1500-luvulla Walesissa olemasta johtuen mm. musiikillisten trendien muuttumisesta, walesilaisen aateliston lisääntyneestä muutosta Lontooseen sekä Englannin lisääntyneen poliittisen painostuksen takia. Siten vanha musiikkikulttuuri menetti olemassaolon edellytyksiään liian paljon ja liian nopeasti. Caerwysissa vuosina 1523 ja 1567 järjestetyt eisteddfodit eivät tuoneet ratkaisua vanhan tyylin soittajien ja runoilijoiden ongelmiin, ja noina aikoina syntyneet runot, kulttuurinsa viimeiset hätähuudot, kuvaavat edustajiensa ajatuksia hyvin.

Mae'n darfod y glod, y glêr - ni cherir

$\mathrm{Na}$ chwarae na haelder,

Na gwyliau, pan eu gweler,

Nac aberth rad nowddgad Nêr.

Ilo on lopussa; runoilijoita ei rakasteta enää, ei viihtymistä, eikä anteliaisuutta, enää ei juhlita, kun olisi juhlan aika, eikä saada ruhtinaalta lahjoja, jotka auttaisivat taistelussa.

\section{(G. Thomas 1968, 32-33.)}

$\mathrm{Ne}$ ilmeisen hyvää tarkoittaneet aateliset, jotka kirjoittivat tai kirjoituttivat bardista kulttuuria koskevia asioita muistiin mutta eivät itse ymmärtäneet saamaansa informaatiota ja sen erikoista kieltä, musiikillisen ilmaisun keinoista puhumattakaan, vaikuttivat ehkä tahtomattaankin bardisen kulttuurin kuolemaa jouduttavasti. Kirjoitettu tai nuotinnettu versio kuulonvaraisuuteen perustuvan musiikin elementeistä on kalpea ja vajavainen toteutus alkuperäisestä, vaikka kysymyksessä olisikin cerdd dant -musiikin kaltainen ilmiö, joka sisältää paljon kulttuurin sisällä sovittua toistoon ja vakiintuneeseen käytäntöön perustuvaa musiikillista tekstiä. Jos vastaanottaja ei ymmärrä näitä rakenteita, jäävät hänen pyrkimyksensä puolitiehen. Tämä toki pitää paikkansa molemmin päin; musiikkia, sen käsitteitä ja rakenteita kuulonvaraisesti oppinut ja sitä kautta ymmärtävä ei kykene siirtämään musiikillista tietämystään kirjoitettuun muotoon. Molemmissa tapauksissa kirjoitettu versio stereotypifioi alkuperäisen tekstin.

${ }^{40}$ Ks. O' Sullivan (1983 I). 


\section{Cerdd dant -performanssi ja sen siirtäminen tabulatuuriin}

Huomautettakoon vielä tässä yhteydessä, että ne cerdd dantin muutamat nimeltä tunnetut säveltäjät (mm. Dafydd Athro, Ieuan ap y gof, Cadwgan), joiden teoksia on Crossley-Hollandin (ibid) mukaan ap Huw MS:n kappaleiden yhteydessä, vaikuttivat 150-300 vuotta ennen Robert ap Huw'ta itseään. Joko 1) heidän sävelmänsä (rakennetyyppeineen, mesureineen ja muineen) olivat siirtyneet kuulonvaraisen transmission kautta Robert ap Huw'n omaan aikaan, ${ }^{41}$ tai 2) ne olivat olemassa jonkun tekemässä kirjoitetussa muodossa, ehkäpä Penllynin kirjassa ja jopa samansisältöisellä otsikolla varustettuina. Kummassakaan tapauksessa ei ole mahdollista todistaa alkuperäisten kappaleiden ehdottoman muuttumattomuuden puolesta eikä, joitakin elementtejä lukuunottamatta, ehdottomasti sitä vastaankaan.

Ensimmäinen vaihtoehto, kuulonvarainen välittyminen, on muuttuvien tekijöiden ja siten "emoversiosta" etäännyttävien seikkojen suuremman määrän suhteen sinänsä hyvin selkeä. Transmissioketjussa viimeistään "emoversion" soittajasta seuraava on muuttumista ja muuntelua suorittava osatekijä. Hänen soittotekniikkansa ja fraseerauksensa erilaisuus, fysiologiset eroavaisuutensa ketjun ensimmäiseen soittajaan nähden, soittimensa erilaisuus (koko, materiaali, kielet) sekä toisenlainen omaksumis- ja edelleenvälittämiskykynsä ovat kaikki muuttumista edesauttavia tekijöitä. Hänen versionsa alkuperäisestä sisältää varmasti riittävän määrän tunnistettavia elementtejä (muutenhan häntä ei olisi varmaan hyväksytty eisteddfodien yhteydessä järjestetyissä virallisissa soittotutkinnoissa), jotta toteutuksen voidaan katsoa kuuluvan tradition piiriin. Sitä emme kuitenkaan pysty todistamaan, missä määrin hänen versionsa aikoinaan erosi originaalista, kun kumpaakaan ei voida mitenkään rekonstruoida. Ja oliko originaaliakaan olemassa vain yksi ainoa versio? Saman kulttuurin sisällä eläneiden, mutta eri soittajien välityksellä sävelmä aikanaan päätyi Robert ap Huw'n ainoaan säilyneeseen käsikirjoitukseen ja kirjalliseen muotoon, ties monennenko informaatioketjun edustajan jälkeen.

Siirrettäessä musiikillista performanssia tabulatuuri- tai muuhun notaatioon ovat tietyt elementit helpommin siirrettävissä kuin toiset. Näihin helpommin siirrettäviin ovat Robert ap Huw'n tapauksessa kuuluneet ne, jotka selvimmin edustivat cerdd dant -musiikissa reproduktiivisuutta. Niitä oli koulutuksen aikana harjoiteltu runsaasti, niiden toteutuksia oli opittu ulkoa, niitä oli opittu soveltamaan ja niissä oli havaittavissa olevaa säännönmukaisuutta riittävä määrä. Vaikeammin nuottikirjoitusformaattiin siirrettäviä näyttävät olleen pintarakenteeseen kuuluvat kerrostumat, joissa muuntelua oli enemmän. Jos ajattelemme esimerkiksi ap Huw MS:n sivulla 35 olevia 'näppäilyaapisen' kuvioita, voinemme olettaa niiden olleen erityisen keskeisellä sijalla cerdd dantissa ja sen oppimis-

\footnotetext{
${ }^{41}$ Ap Huw saattoi oppia ne William Penllyniltä.
} 
prosessissa, vaikkakaan näiden hallintaa ja nimiä ei mainita bardisen koulutusputken eri vaihessa vaadittavien asioitten yhteydessä kirjallisissa lähteissä lainkaan. Äskeinen oletus perustuu "Dosbarth Gerdd Dannaussa" ja muissa kirjoituksissa oleviin mainintoihin plethiadien, tagiadien jne. tärkeydestä:

Tästä johtuen me puhumme sitomisista (crychiadau), punoksista tai toistoista (plethiadau), konjunktioista (cysylltiadau), lyömisistä (tagiadau), pysäytyksistä (ystopiadau). Huomioikaa syy miksi konjunktioita nimitetään niin - koska ne yhdistävät perussävelen ja näppäilyn..., lyöminen, koska se pysäyttää perussävelen ja näppäilee sen, kun sen vuoro tulee; sitomiset sijoittuvat perussävelen ja näppäilyn väliin, ja missä sormi on, se huomioidaan. Välit (toleiadau) ovat jousitusten paikalla ja toistot harmonisoivat vetojen ja perussävelten välillä, vaihdellen ja luoden eroja."

(Ap Huw MS, johdanto)

Sen sijaan on hämärän peitossa, milloin näille teknisille termeille olisi ensi kerran kehitetty graafiset symbolit. Näin on tehty kuitenkin viimeistään 1500 -luvulla päätellen käsikirjoituksen 'Clymmau Gytgerdd' -osiosta. Niitä on voitu harjoitella aluksi puhtaasti teknisinä, musiikillisesta ilmaisusta irrallaan olevina yksikköinä, sitten cyweirdannau-tyniad yhdistelmänä, edelleen mesuriin ja sitä kautta vakiintuneisiin rakennetyyppeihin sovellettuina. Kuinka helposti tai vaikeasti näiden siirto onnistui esimerkiksi caniadeihin, joissa mesureihin perustuva säännönmukaisuus ei ole läheskään niin selvä kuin esim. cwlwmissa?

Caniadien suuri lukumäärä eri tutkintoasteissa voidaan tulkita, paitsi niiden keskeisen aseman vuoksi runon, laulun ja soitinmusiikin poikkitaiteellisina edustajina bardisessa kulttuurissa, ehkä myös siksi, että niiden musiikillisessa sisällössä oli enemmän yksilöllisyyttä kuin gostegeissa ja cwlwmeissa. Sen vuoksi niitä oli vaikeampi merkitä kirjoitettuun muotoon, ja niiden säilyttäminen repertoaarissa kuulonvaraisen transmission kautta voimakkaammin korostui.

Huomautettakoon vielä tässä yhteydessä, että käsitykseni säännönmukaisuudesta perustuu ensisijaisesti Robert ap Huw -käsikirjoituksen sisältämiin esimerkkeihin cwlwmeista ja gostegeista.

\section{Kaksi esimerkkitapausta: 'Cwlwm gytgerdd' ja 'Caniad San Silin'}

Seuraavat esimerkit 'Robert ap Huw -käsikirjoituksesta' selvittänevät osaltaan edellä esitettyä säännönmukaisuus/yksilöllisyys-dikotomiaa. Sisällysluettelon mukaisessa järjestyksessä gostegien jälkeen ap Huw MS:ssa seuraa joukko 
kappaleita, joiden yhteinen nimike on "clymmau gytgerdd". ${ }^{42}$ Ensimmäinen sivulta 23 alkava kokonaisuus käsittää 24 lyhyttä harjoituskappaletta, kaikki mitassa "mak y mwn hir" eli 111100001010111100001011.

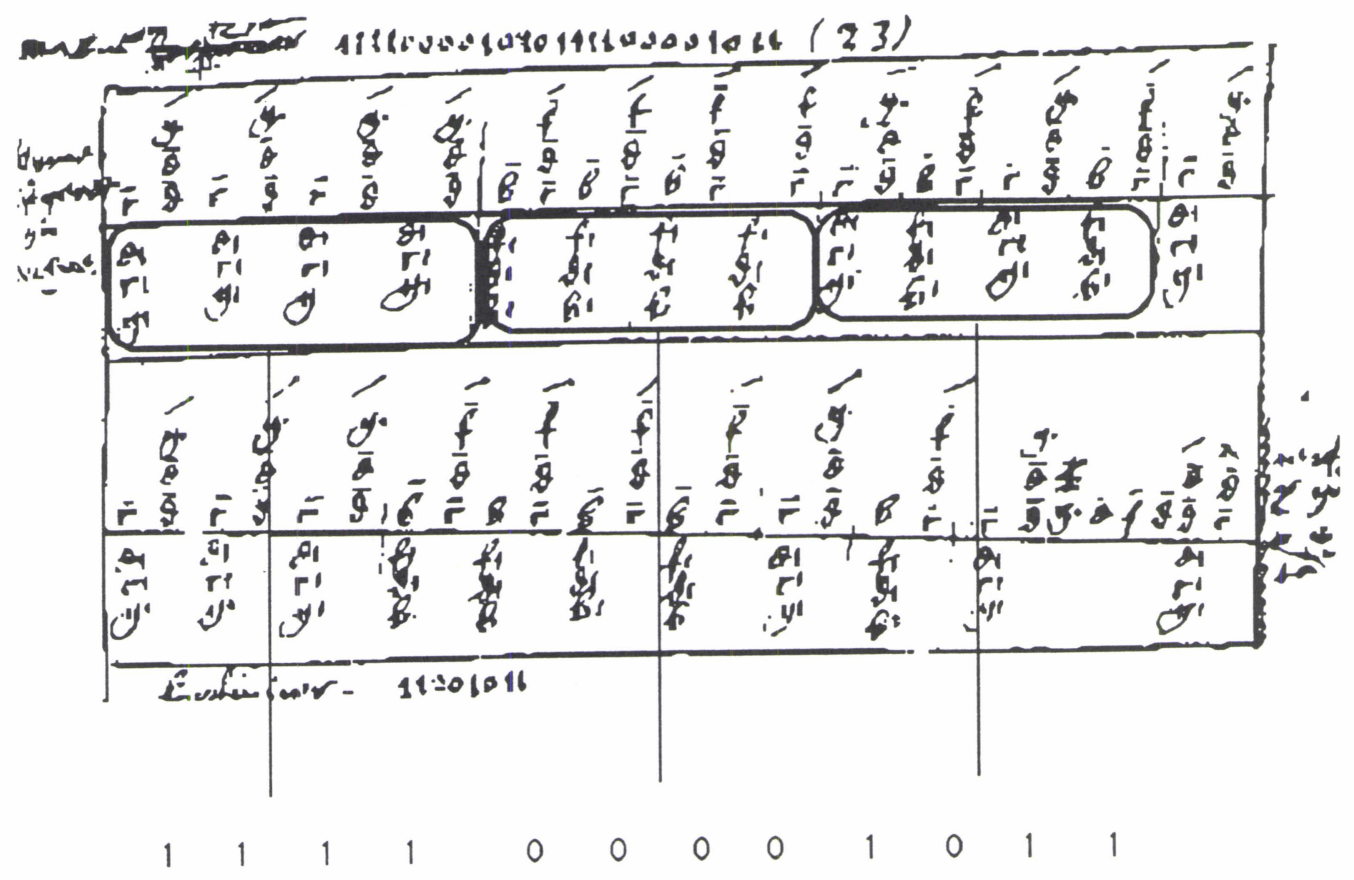

Kuva 3. Robert ap Huw -käsikirjoitus, s. 23: Ensimmäinen harjoituskappale ("cwlwm gytgerdd"), 'cainc' n:o 1. Mesur on "mak y mwn hir" (1111 0000 1010). Mesurin aikaansaama rakenteellinen säännönmukaisuus on selvästi havaittavissa. Ylemmän käden on tarkoitus harjoitella kuviota "plethiad mawr".

Kuvasta huomaamme, että poikkiviivat ovat aina neljän 'cyweirdantin' (1) ja/tai 'tyniadin' (0) jälkeen. Viivat ovat paikoitellen erimittaisia toisiinsa nähden, mutta sitä lienee pidettävä ennemmin Robert ap Huw:n käden liikkeiden tahattomina aikaansaannoksina kuin musiikillisia eroavaisuuksia ilmaisevina merkkeinä. Kun eräässä toisessa käsikirjoituksessa ${ }^{43}$ mainitaan, että "neljä heikkoa cyweirdantia muodostaa yhden vahvan cyweirdantin ja neljä heikkoa tyniadia yhden vahvan tyniadin", yksi mahdollisuus tulkita viivat on ajatella ne "vahvojen" musiikillisten

\footnotetext{
42 'Clymmau ' on monikkomuoto sanasta 'cwlwm', 'gytgerdd' puolestaan viittaa yhteismusisointiin. Kappaleet otsakkeen 'clymmau gytgerdd' alla ovat ilmeisesti tarkoitetut soitettaviksi sekä harpulla että crwthilla.

${ }^{43}$ Panton MS 56.
} 
yksikköjen rajakohtina.

Voi olla, että edellä olevan kaltainen säännönmukainen 'vahva/heikko'vaihtelu koskee vain määrättyjä musiikkityyppejä ('cwlwm', 'gosteg'), ja muissa tapauksissa (esim. 'caniad') vahvan ja heikon vaihtelu ei ole samalla tavalla yksiselitteinen, vaan ne olisi pääteltävä muista musiikillisista tai ulkomusiikillisista (kuten mahdolliset yhteydet runomittoihin) yhteyksistä.

Sivulla 69 alkava, ja jo tämän artikkelin alussa esille tullut "Caniad San Silin" käyköön esimerkkinä caniad-tyypistä. Vaikka kysymyksessä on eräs selvimmin säännönmukaisuuden periaatteilla toimivista caniadeista, on ero edellisen esimerkin cwlwmiin hyvin selvä.
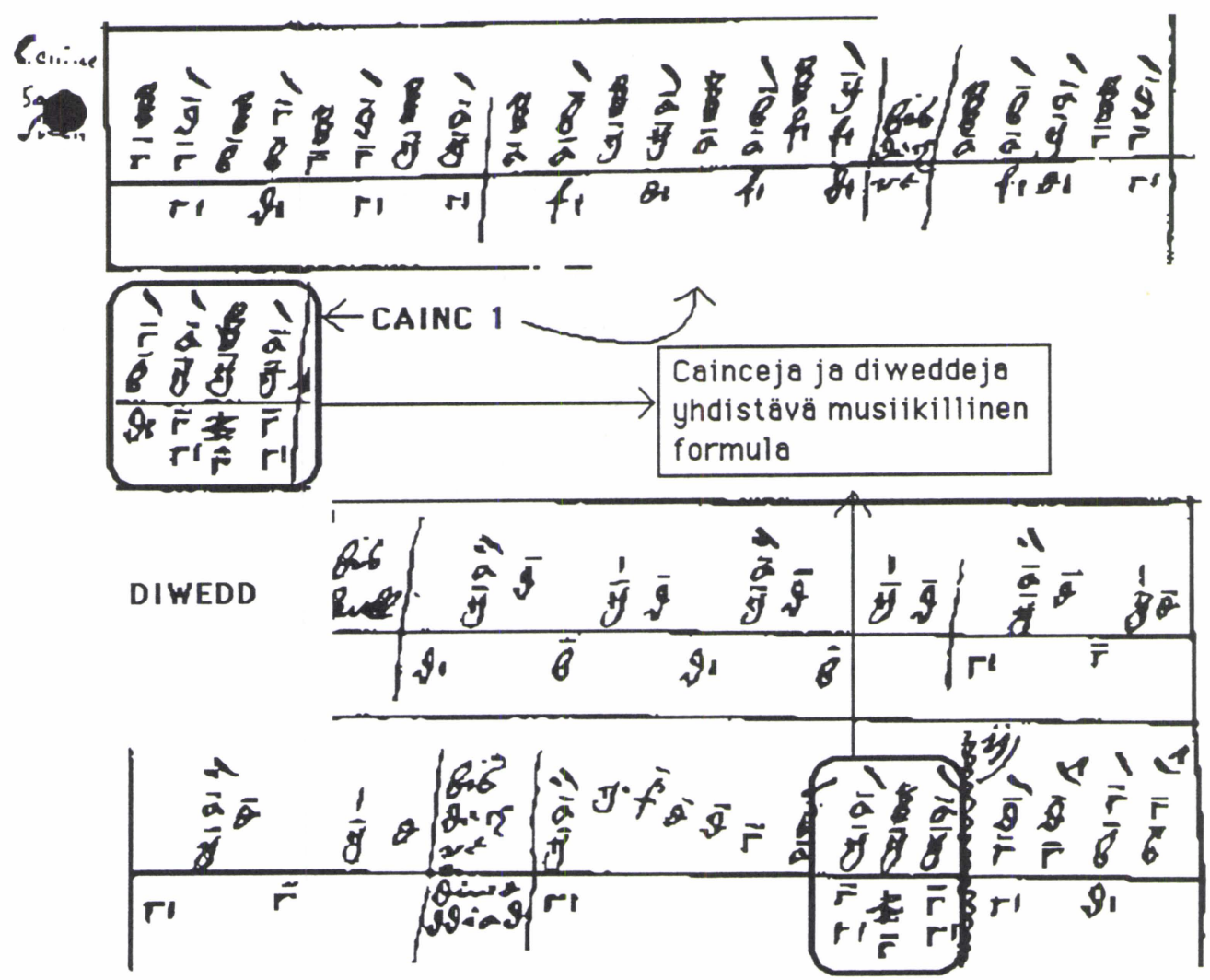

Kuva 4. Robert ap Huw -käsikirjoitus, s. 69: "Caniad San Silinin" alku. Käsiä erottavan viivan alapuoliset merkit eivät muodosta yhtä säännöllistä 'mesuria'. Sekä 'caincin' että 'diweddin' rytminen toteutus antavat useita tulkintamahdollisuuksia.

Jo "Caniad San Silinin" alkuosasta nähdään, että se ei rakenteellisesti ole sidottu yhteen mesuriin, ja että sen harmoniavaihtelut ovat niin ikään monipuolisemmat kuin 'clymmau gytgerdd' kappaleissa. Rytmiikan tulkinnassa ja toteutuksessa on 
myös monta mahdollisuutta. Oma näkemykseni on, että "Caniad San Silin" on heterometrinen; ts. siinä on useampi kuin yksi rytmikaava. Jo ensimmäinen 'cainc' ja sitä seuraava 'diwedd' ovat erimetrisiä.

Toinen esittämäni vaihtoehto, jonka mukaan cerdd dant -musiikkia olisi siirretty kirjalliseen muotoon viimeistään 1500 -luvulla, ei sinänsä vähennä muuntelun ja muuttumisen määrää, vaan ainoastaan kanavoi sen toisella tavalla. Emme varmuudella tiedä, koska Robert ap Huw -tabulatuurin kaltainen merkintätapa kehittyi, kuka sen kehitti ja missä. Lukuisia epämääräisiä viittauksia harpputabulaatuurien olemassaoloon Brittein Saarilla on olemassa, mm. Bunting $^{44}$ väitti irlantilaisilla olleen harpputabulatuurin jo 1100-luvulla. Bardisen koulutusjärjestelmän pitkä kesto, henkilökohtaiseen mestari-oppipoika suhteeseen perustuva tiedon- ja taidonsiirtojärjestelmä, vaatimukset uuden luomisesta ja improvisoinnista, kuvaukset itse oppimisprosesseista sekä jo moneen kertaan mainitut vakiinnutetut musiikin rakenne-elementit puhuvat kuitenkin oraalisen kulttuurisiirron puolesta ja merkityksestä.

Mitä tabulatuurissa käytettyyn merkkijärjestelmään tulee, on mahdotonta sanoa, olisiko se jo ensimmäisissä vaiheissaan ollut samanlainen kuin Robert ap Huw'n aikana, mikäli se ylipäänsä oli olemassa ennen hänen tai William Penllynin aikaa. Jos se on kehittynyt monien eri vaiheiden kautta siihen muotoon kuin se on ap Huw -käsikirjoituksessa, oliko sen primääri tarkoitus ollutkaan merkitä kaikkia musiikkiesitystä koskevia asioita yksityiskohtaisesti muistiin, vai oliko sen funktio ennemminkin esitysten kannalta keskeisten asioiden, kuten gostegeissa ja cwlwmeissa käytettävien soittoteknisten aspektien ja niiden esiintymisjärjestyksen pitäminen muistissa puuttumatta tarkemmin esimerkiksi rytmin käsittelyyn, joka opittiin kuulonvaraisesti jäljittelemällä? Sivun 35 sisältämästä 'näppäilyaapisesta' puuttuvat harpulle niinkin idiomaattiset seikat kuin arpeggiot ja glissandot, joita esimerkiksi Buntingin muistiinpanoissa löydämme lukuisia, teknisiltä toteutuksiltaan ja symbolisilta nimiltään erilaisia (kts. Kuva 5). On tietenkin mahdollista, että Robert ap Huw katsoi näiden soittotapojen olevan niin tyypillisiä ja harpulle ominaisia, ettei hän nähnyt tarpeelliseksi kirjoittaa niitä ulos, vaan antoi soittajan itsensä päättää niiden käytöstä.

Irlantilaisista soittajista tehtyjen havaintojen ${ }^{45}$ pohjalta glissandoilla ja arpeggioilla näyttää kuitenkin olleen erittäin keskeinen merkitys kappaleen sisäisen dramatiikan kannalta, samoin kuin erityyppisillä yhden tai useamman sormen tremolokuvioilla, jollaiset ap Huw puolestaan on merkinnyt hyvinkin tarkkaan toisistaan erotellen. Onko kysymys alueellisista tyylieroista, erilaisten seikkojen korostamisesta suhteessa soittajien kykyihin ja makuun? Oli miten hyvänsä, kuulonvaraisuuden ja siihen liittyvän muuntelun merkitystä ei tässäkään voi sysätä syrjään. Mitäpä olisivat Carolanin ja Dennis Hempsonin kaltaiset sokeat

\footnotetext{
${ }^{44}$ Bunting 1809; $x$.

${ }^{45}$ Bunting 1809 ja 1840 (esipuheet).
} 
harpistit todellakaan tehneet visuaaliseen ensihavaintoon perustuvalla graafisten symbolien järjestelmällä?

\section{SIVU 35: Näppäilyn aakkoset}

(Gogwyddor i ddysgu i prikiad)

1. Tagiad y fawd (peukalolla sammutus)

2. Y plethiad byr (lyhyt punos)

$\frac{\mathrm{a}}{\mathrm{g}}$

3. Plethiad y pedwarbys (neljän sormen punos)

4. Plethiad y bys bach (pikkusormen punos)

5. Krafiad dwbl (kaksoisraapaisu)

6. Krafiad sengl (kertaraapaisu)

7. Haner krafiad (puoliraapaisu)

8. Tafliad y bys (sormen heitto)

9. Plethiad dwbl (kaksoispunos)

10. Plethiad y wanhynen (mehiläisen punos)

11. Krychu y fawd (peukalorypistys)
(Gogwyddor prikiad arall)

$\frac{\frac{1}{a}}{\frac{a}{g}}$

Robert ap Huw Tulkinta (1)

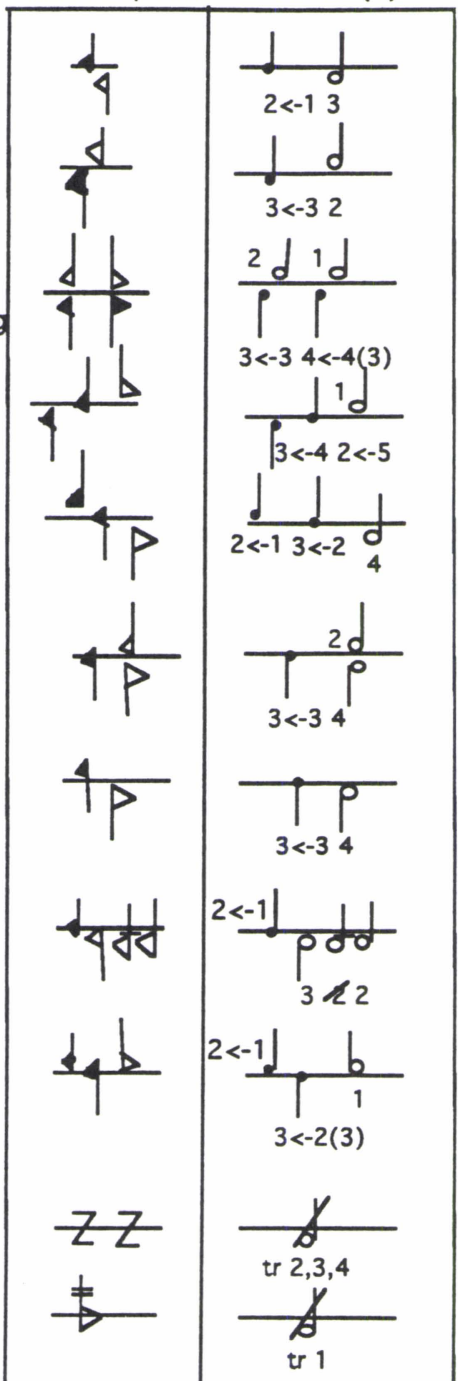

Kuva 5. Osa ap Huw MS:n sivulla 35 olevista soittotapoja koskevista merkeistä. Oikeanpuoleinen sarake esittää tulkintaehdotuksen, joka on yhdistelmä Paul Whittakerin (1974), Robert Evansin ja allekirjoittaneen näkemyksiä. Mustalla merkityt kielet/nuotit sammutetaan, avopäiset jätetään soimaan. 


\section{Ap Huw MS ja sen koodin tulkinta}

On tietysti monia tapoja käsitellä ja pyrkiä ymmärtämään ap Huw MS:n sanoma. Hyvin vaarallisena ja harhaanjohtavana pidän lähtökohtaa, jonka mukaan käsikirjoituksessa on kaikki se musiikillinen ja muukin tarvittava informaatio, joka sisältyy tyyliin nimeltä cerdd dant. Ilman cerdd dantin peruselementtien ja syvärakenteiden, sen ainutlaatuisten ominaispiirteiden tunnustamista ja vilpitöntä pyrkimystä niiden ymmärtämiseen tradition itsensä ehdoilla, on meidän mahdotonta toivoakaan löytävämme itsestämme pientä bardisen koulun oppilastyyppiä kilvoittelemassa kohti 'pencerddin' arvoa. Jos Robert ap Huw itse ymmärsi kirjoittamansa osana sitä lukuisten tekijöiden muisti- ja keinovarastoa, jolle cerdd dant tyylinä, traditiona tai musiikkiekonomiana rakentui, on nykypäivän tutkijan ja muusikon myös koetettava lähestyä sitä niin paljon sisältäpäin kuin mahdollista. Näin siitäkin huolimatta, ettei spekulointia jossain määrin voi välttää. Ei Beethovenin sinfonioistakaan ole vielä tehty sitä viimeistä, kaiken "objektiivisen ja oikean tiedon" sisältävää levytystä.

Notaation olemuksesta eri aikakausien musiikissa Treitler $(1990 ; 47)$ toteaa modernissa nuotinnosjärjestelmässämme yksittäistä nuottia pidettävän perusyksikkönä. Gregoriaanisessa laulussa taas vanhimmassa kirjoitetussa transmissiomuodossa perusyksikkönä on neumi, mikä tavallisesti ilmaisee useampaa kuin yhtä sävelkorkeutta ja jotka lauletaan saman tavun aikana peräkkäin. Yksittäistä sävelkorkeutta ilmaisevat neumit kirjoitetaan tavallisesti vain silloin, kun yksittäinen sävelkorkeus vastaa samalla yhtä tavua. Gregoriaanisen laulun nuotinnoksessa yksi tavu voi käsittää useamman kuin yhden neumin, ei päinvastoin.

Toinen tapa ilmaista sama on, että neumien ja tavujen rajat yhtyvät. Tämä on peruskonseptio, mikä määräytyy melodian luonteesta ja sen suhteesta kieleen; neumit esittävät melodian liikeratoja, joihin tavut on intonoitu. Tavun vokaali voi kestää monta neumia, mutta yhden neumin aikana ei voi esittää useamman tavun muodostamaa ketjua. Treitlerin esille tuoma konseptio olisi jättänyt jälkensä myös sanan "neumi" etymologiaan. ${ }^{46}$ Hän esittää hypoteesin, jonka mukaan vanhoissa notaatioissa esiintyvät neumien ryhmittelyt (neumien edustamat nuottiryhmät), jotka monissa käsikirjoituksissa esiintyvät lähes identtisinä tai ainakin samantyyppisinä, esittäisivät pyrkimystä siirtää kuulonvarainen laulutraditio kirjoitettuun muotoon. (1990; 47-48)

Treitler toteaa voivan tuntua paradoksaaliselta väittää (kuten hän siis tekee), että nuottikirjoituksen varhaisimmat manifestaatiot ja niiden systeemit piirteineen antaisivat aiheen tulkita ne [kuulonvaraisesti välittyneeseen] musiikkiesitykseen perustuviksi, eli toisin sanoen pyrkimyksiksi siirtää kuulonvaraisesti opittu

\footnotetext{
${ }^{46}$ Latinankielinen sana 'neuma' pohjautuu moniin kreikan kielen juurisanoihin, joista yksi on 'pneuma' - hengitys. Treitlerin mukaan 'neuma' viittaisi melismaan, joka laulettiin yhdellä tavulla ja yhdellä hengityksellä $(1990 ; 47)$.
} 
esityskäytäntö ja siihen liittyvät elementit paperille. Erittäin olennainen on mielestäni Treitlerin esittämä kysymys "... kuinka voidaan kehittää kirjoitusjärjestelmä sellaisille periaatteille nojaten, jotka ovat vastakkaisia siihen traditioon varastoiduille konseptioille, joita järjestelmän on tarkoitus tallentaa?" (ibid; 51: kursivointi kirjoittajan) Näin nuottikirjoitus, ensimmäisessä vaiheessaan, toimisi katalyyttinä toteuttaa muitakin julkaisuja, joiden olemassaolo puhtaasti oraalisessa kulttuurissa olisi ollut tuskin mahdollista tai kuviteltavissa. Suunnilleen samanaikaisesti notaation alkuvaiheiden kanssa syntyivät ensimmäiset [länsimaisen musiikin] esteettiset ja teoreetiset kirjoitukset - käytännön tarkoitusta silmälläpitäen - jotka vahvistivat ja monimutkaistivat/jäykistivät saman konseptuaalisen transformaation. Viitaten Treitlerin aiemmin mainitsemaan karolingien keskeiseen rooliin notaatiojärjestelmän kehittämisessä, sen tavoitteena oli (karolingilaisessa hengessä) normalisoida ja yhdenmukaistaa gregoriaanisen liturgisen laulun esityskäytäntö ja kuvata sekä luokitella laulut niiden modaalisen järjestelmän mukaan (ibid., 51).

Jos edellä olevaa soveltaa 'Robert ap Huw -käsikirjoituksen' käyttämään merkkijärjestelmään, löytyy runsaasti yhdenmukaisuuksia ja seikkoja, jotka puoltavat Treitlerin hypoteesia "kirjoitusjärjestelmästä, joka nojaa sen [kuulonvaraisen] tradition perusteille, jotka sillä on tarkoitus tallentaa." Ap Huw MS:n sivulla 35 olevat soittotapaesimerkit symbolisine nimityksineen ja niihin liittyvine merkkeineen sopisivat hyvin kuulonvaraisissa oppimisprosesseissa omaksuttujen teknisten suoritusten visuaalisiksi merkintätavoiksi. Monien tabulatuurissa käytettyjen merkkien, kuten 'plethiad wanhynen' tai 'krychu y fawd', jo itse graafinen symboli tuo mieleen soittoteknisen suorituksen:

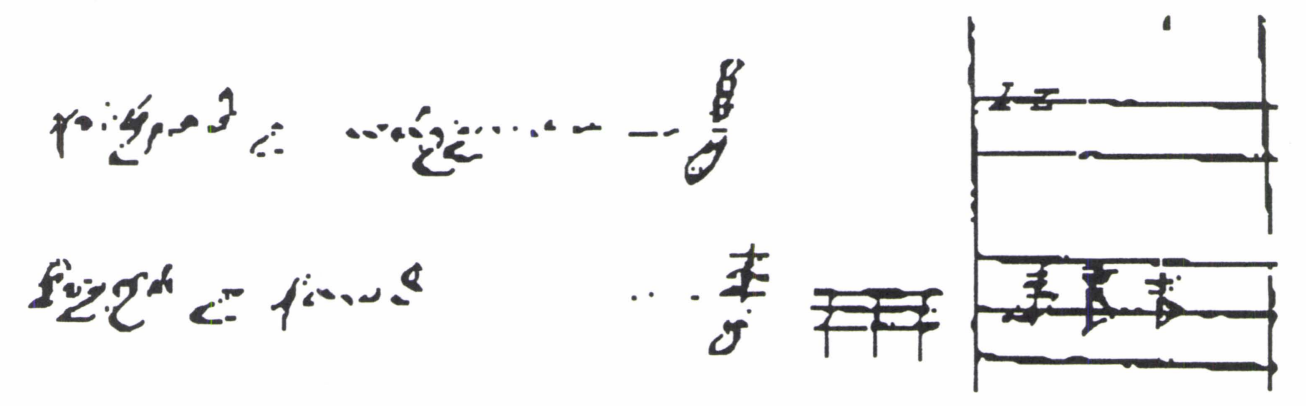

Kuva 6. Ylempänä 'plethiad y wanhynen' (mehiläisen punos) ja sen alapuolella 'krychu y fawd' (peukalon rypistys). Ylempi suoritetaan sormien 2,3 ja 4 nopeana tremolona, alempi peukalon edestakaisella liikkeellä.

Jos pidämme kiinni ajatuksesta, että ap Huw MS on ensimmäinen (tai eräs ensimmäisistä) pyrkimyksistä merkitä pysyvässä muodossa muistiin cerdd dant musiikkia, ja kun vielä huomioimme, että ensimmäiset tähänastisten tutkimusten perusteella todistetut 'cerdd dantia' koskevat musiikkiteoreettiset ja muut kirjoi- 
tukset ovat peräisin vasta 1500 -luvulta, ${ }^{47}$ on hyvin mahdollista, ettei ap Huw MS:ssa käytetyn tabulatuurinotaation kaltaista systeemiä ollut olemassa ennen 1500-lukua, mahdollisesti sen puoliväliä (ts. periodia, johon William Penllynkäsikirjoitus voisi sijoittua). Siten Buntingin (ja monen muun) väittämä, että edellä mainitun kaltainen kirjoitusjärjestelmä olisi ollut olemassa ja käytössä jo 1100-luvulla ei pitäisi paikkaansa.

Aiemmin jo moneen kertaan esiin tulleeseen näkemykseen ap Huw MS:n musiikillisen sisällön iästä (aikaväli n. 1270-n. 1450) viitaten on mahdollista, että käsikirjoituksen sivulla 35 esitetyt soittotavat nimityksineen ovat olleet olemassa osana kuulonvaraisesti välittynyttä traditiota jo kauan ennen Robert ap Huw'n omaa aikaa. On vaikea sanoa, mitkä niistä edustavat vanhempaa ja mitkä nuorempaa kerrostumaa, ja olisiko jotkut niistä kehitetty vasta Robert ap Huw' n omana aikana. ${ }^{48}$ Voimme toki spekuloida ajatuksella, että yksittäisillä etuheleillä varustetut kuviot edustavat vanhinta kerrostumaa $\mathrm{mm}$. sillä perusteella, että vastaavan tyyppisiä esiintyy jo varhaisessa francolaisessa koraalinotaatiossakin. ${ }^{49}$ Kuitenkin, mikäli keskiajalla luodulle ja sieltä periytyvälle soitinmusiikille, joka tässä nimenomaisessa tapauksessa on siirtynyt oraalisen transmission kautta ja jossa on siirtymäprosessin aikana tapahtunut runsaasti muuntelua, kehitetään kirjallinen tallentamisjärjestelmä vasta 1500-luvulla, eräissä tapauksissa siis useita satoja vuosia joidenkin säveltäjien omaa aikaa myöhemmin, se joko kuvastaa (1) suurta huolta kyseisen musiikkikulttuurin säilymisen ja jatkumisen puolesta tai (2) tarvetta tehdä musiikillinen todellisuus ymmärrettävämmäksi muille.

Olen edellä viitannut cerdd dant -musiikin eri osa-alueiden kuvauksia sisältävien walesilaisten käsikirjoitusten toisiinsa nähden hyvin ristiriitaisiin ja vaikeasti tulkittaviin kirjoituksiin, ja otaksunut yhtenä syynä siihen olevan kirjoittajien itsensä liian ulkopuolisen suhteen kuvaamaansa kulttuuriin nähden. Kuitenkin he, antiikin ja samalla oman alueen antiikin kulttuuria kunnioittavina, pyrkivät mitä ilmeisimmin tekemään parhaansa, jotta mahdollisimman paljon olennaista vanhan musiikkikulttuurin sisällöstä voitaisiin tallentaa ja siten säilyttää pysyvässä muodossa. Bardinen kulttuuri oli, monista sen ulkopuolelta tulleista syistä ja ehkä myös omasta tietynlaisesta sisäisestä jäykkyydestään ja haluttomuudestaan muuttua, kuitenkin tullut tiensä päähän, ja jotkut sen edustajat ja suosijat pitivät välttämättömänä saada edes jotain siitä tallennettua. On tietysti mahdollista, että Robert ap Huw ja muut tuolloin vielä cerdd dant -kulttuurissa vaikuttaneet saattoivat myös pyrkiä tekemään musiikkinsa laajemmin ymmärrettäväksi. Jos kuitenkin huomioimme notaatiosysteemin vajavaisuuden kuvaamaan riittävästi

\footnotetext{
47 Vanhin on Peniarth 60 n. vuodelta 1500 ja Pohjois-Walesista. Myös ajallisesti varhaisimmat viittaukset 'mesurauhin' samalta alueelta, samoin kuin 'cyweirdantiin'. Viereinen perustuu Daniel Huws'n Bangorin symposiumin yhteydessä 1995 esille tuomaan tutkimustulokseen.

${ }^{48}$ Käsikirjoituksen William Penllyn-osion kappaleet sisältävät vain osan sivun 35 kuvioista, ja ko. sivulla olevat soittotapamerkit vain osan koko käsikirjoituksessa olevista. ${ }^{49}$ Plica.
} 
musiikillisessa performanssissa tapahtuvia asioita, tekijöidensä omat puutteelliset kyvyt hyödyntää tabulatuurikirjoitusta, sekä lisäten tähän kahden erilaisen kulttuurimaailman (vanha bardinen vastaan tudorilainen) yhteensovittamattomuuden, Englannin hallinnon aikaansaaman poliittisen ja muun painostuksen, sekä (mahdollisesti edellisistä johtuen) vanhan bardisen kulttuurin suojelijajärjestelmän lakkaamisen, ei liene ihme, että monet ap Huw MS:ta ja cerdd dantia koskevat kysymykset ovat edelleen jääneet vastausta vaille. Kun vanhaa kulttuuria aiemmin suosinut aatelisto muutti Walesista pois ja lopetti tukensa bardiselle järjestelmälle, ei uusia perinteenjatkajia enää ilmaantunut.

Kysymys, mitä Robert ap Huw'n musiikille tämän kuoleman jälkeen tapahtui on niin ikään tyhjentävää vastausta vailla. Walesilaisen musiikin tutkimuksissa ${ }^{50}$ on koetettu etsiä merkkejä bardisen kulttuurin ja cerdd dantin siirtymisestä osaksi myöhempiä musiikillisia kerrostumia, erityisesti kansanmusiikissa, mutta toistaiseksi tuloksetta. On tosin olemassa erilaisia viittauksia vanhoihin bardisiin käsitteisiin, mm. eräissä käsikirjoituksia 1700-luvun loppupuolelta.

Huomionarvoista kuitenkin on, että 1600-luvulta ei löydy kirjallista tietoa eikä nuotinnoksia (ap HuwMS:a lukuunottamatta, joka on siis luku erikseen) bardisten sävelmien siirtymisestä tai juurtumisesta Walesin musiikkielämään. Myöskään ap Huw MS:n sisältämien sävelmien nimiä (tai edes sinne päin viittaavia) ei löydy myöhemmistäkään lähteistä ennen vuotta 1802, jolloin Edward Jones julkaisi kirjansa "Bardic Museum". ${ }^{51}$ Voidaan olettaa, että aiemmin tarkasti varjeltu sisäpiirin kulttuuri, yrittäessään olemassaolonsa viime vaiheissa siirtää itsestään jotain tuleville sukupolville, oli musiikilliselta sisällöltään ja käsitteistöltään niin vieras, ettei sen siemen löytänyt enää kasvualustaa vastaanottajan maaperässä. Bardista kulttuuria pidettiin myös vanhanaikaisena ${ }^{52}$ ja mielenkiinnottomana verrattuna niihin uusiin musiikillisiin trendeihin, jotka olivat muodissa niin englantilaisten kuin walesilaisten keskuudessa 1500/1600-lukujen vaihteessa.

Monessa yhteydessä on kysytty, miksei Robert ap Huw kirjoittanut musiikkiaan nuoteille. ${ }^{53}$ Aiemmin esittämäni hypoteesin mukaan tabulatuurissa käytetty merkkijärjestelmä on yritys siirtää kuulonvaraisessa harppumusiikissa kielten nimet (ei siis ensisijaisesti sävelkorkeudet), soittotekniset seikat sekä keski- ja syvärakenteet (mesurit, kompositiotyypit) pysyvään muotoon. Cerdd dantin soittotapojen kuvaukseen moderni notaatio on kaikkea muuta kuin hyvä systee-

\footnotetext{
${ }^{50}$ Tutkimustyötä tämän ongelman parissa ovat tehneet mm. Phyllis Kinney, Meredydd Evans ja Robin Huw Bowen.

${ }^{51}$ Jonesin kirjassa on mm. kappaleet nimeltä 'Pibau Morfydd' ja 'Hun Gwenllian', jotka niminä esiintyvät myös ap Huw MS:ssa. Musiikillisesti Jonesin kappaleilla ei kuitenkaan ole mitään tekemistä bardisen cerdd dantin kanssa, vaan ne edustavat varhais(kansallis)romanttista triple harp musiikkia.

${ }^{52}$ Ks. G. Thomas (1968).

${ }^{53}$ Robert ap Huw mitä ilmeisimmin tunsi oman aikansa mensuraalinotaation, varsinkin jos hän todella toimi Englannin hovissa hovimuusikkona (ks. tarkemmin William, op.cit.).
} 
mi; seikka, mikä on käynyt ilmi tähän mennessä tehdyistä transkriptioista modernille nuottikirjoitukselle. Lukuisissa 1500- ja 1600-luvun walesilaisissa käsikirjoituksissa on pyritty selittämään musiikkikäsitteistöä, terminologiaa, virityksiä, sävelmien nimiä ja niissä käytettyjä mesureja, kuten on jo ollut puhetta. Samoin on ollut puhetta, kuinka cerdd dantia käsittelevien kirjoitusten kohdalla näyttää käyneen niin, että käsikirjoituksen tekijöille itselleen kyseisen musiikkikulttuurin maailma ei ole avautunut riittävästi. Sen koodikielen realisoiminen olisi edellyttänyt käytännön harjoittelua kuulonvaraisessa oppimisprosessissa, mitä ei näytä tapahtuneen.

Ymmärrän Robert ap Huw -käsikirjoituksen tabulatuurinotaation nimenomaisesti kuulonvaraisen musiikkikulttuurin yrityksenä siirtää kirjoitettuun muotoon, jonka koodin avaaminen voi toteutua ainoastaan kyseisen kulttuurin mahdollisimman pitkälle saatetun sisäistämisen kautta. Sisäistämiseen kuuluu jo moneen kertaan esille tulleet keski- ja syvärakenteiden (aiemmin jo useaan kertaan mainittujen lisäksi myös idiomaattiset seikat, kotoperäinen terminologia, kulttuurin sisäinen musiikillinen diskurssi ja siihen vaikuttaneet sisä- ja ulkopuoliset tekijät, sosiaalinen ja uskonnollinen konteksti ja sen mukanaan tuomat tekijät, yhteydet muihin bardisiin taiteisiin, erityisesti runouteen ja tarinankerrontaan) tutkiminen ja niistä johtopäätösten tekeminen. Tabulatuurinotaatio on näin ollen aikaperspektiivillä ajateltuna nollapiste tutkimusmatkalla ajassa ja kontekstuaalisuudessa taaksepäin.

\section{Lopuksi}

Edellä olen koettanut selvittää näkemyksiäni cerdd dant -musiikista ja ap Huw MS:sta. Olen pyrkinyt osoittamaan (musiikki)kulttuurin eemisen puolen mahdollisimman hyvän ymmärtämisen ja tuntemisen tärkeyden myös vanhan musiikin tutkimuksessa, vaikkakin alkuperäisten informanttiemme harput ja crwthit ovatkin jo satoja vuosia sitten vaienneet. Olen toivoakseni voinut riittävän perustellusti osoittaa, miksi ap Huw MS:n (joka itsessään on jo transkriptio, josta puuttuu määrättyjä dimensioita soivasta todellisuudesta) sisällön paremman ymmärtämisen kannalta meidän lähtökohtamme ei voi olla tabulatuurinotaation siirtäminen moderniin notaatioon, joka olisi siis vielä yksi transkriptio lisää. Alkuperäistä käsikirjoitusta voimme pitää kontekstuaalisena notaationa, josta koodikielen hallinnut muusikko saattoi toteuttaa kulttuurin kannalta tyylinmukaisen realisoinnin. Toteutusvaihtoehtoja oli epäilemättä useita.

Jos sen sijaan pyrimme vain muuttamaan tabulatuurissa käytetyt graafiset merkit nykyaikaiseksi nuottikirjoitukseksi lainkaan problematisoimatta itse alkuperäiseen kirjoitukseen johtaneita syitä sekä siinä aikaansaatua koodijärjestelmää avaimineen, päädymme kuvitellun oikotien sijasta helposti oikosulkuun. Kun siirrämme jotakin joksikin toiseksi, muutamme alkuperäisen informaatiosisällön toiselle kielelle, jolla on joko hyvin vähän tai ei mitään tekemistä 
originaalin kanssa. Jos käännämme swahilin kielisen laulun englanniksi, voimme siirtää siinä yhteydessä alkuperäisen tarinan juonen (jos se on tarkoituksemme), mutta emme alkuperäiskielelle ominaisia äänteitä, kurkunpäänväristyksiä ja glissandoja, jotka ovat aivan olennainen osa alkuperäistä äänimaisemaa ja joita ilman varsinaisiin sanoihin sisältymättömät mutta laulun sanomaa olennaisesti tehostavat musiikillisen esityksen osatekijät jäävät tulematta esiin. Vastaavasti; jos siirrymme kontekstuaalisesta notaatiosta, joka oli tarkoitettu muusikon itsensä realisoimaksi erilaisten tyylillisten vaihtoehtojen puitteissa, standardiin nykyversioon, jossa on yksityiskohtaiset käyttöohjeet, muuttuu alkuperäinen määrättyjä vapauksia antava nuotinnos tiukaksi esitystä koskeviksi säännöiksi. ${ }^{54}$ Kun kerran ap Huw MS:n tabulatuurinotaatio on omasta kulttuurisesta maaperästään noussut musiikillisen informaation toteutustapa, tulisi sen yhdessä muiden kyseisen kulttuurin tutkimuksesta tehtyjen havaintojen ja johtopäätösten kanssa olla musiikillisten rekonstruktioiden lähtökohta.

\section{Lähteet}

Bent, Margaret 1994. Editing early music: the dilemma of translation, Early Music, vol. XXII, n:o 3. Oxford University Press: Lontoo.

Blum, Stephen 1993. Analysis of Musical Style, Teoksessa Ethnomusicology: an Introduction, 165-217. W.W. Norton \& Co: New York.

Bunting, Edward.1969. A General Collection of the Ancient Irish Music, vol. I (1796), vol. II (1809), vol. III (1840). Walton Publications Ltd: Dublin (faksimilepainos, jossa kaikki kolme osaa samassa niteessä).

Burstyn, Shai 1984. Gerald of Wales and the Sumer Canon. The Journal of Musicology, Vol. II, No. 2: 135-151.

Crossley-Holland, Peter 1942. Secular Homophonic Music in Wales in the Middle Ages. Music and Letters, Vol. XXIII, No.2: 135-162. Cambridge.

Dart, Thurston 1974. Robert ap Huw's Manuscript of Welsh Harp Music (1613), The Galpin Society Journal, Vol. XXI: 52-65. Lontoo.

Dolmetsch, Arnold 1937. Translations from the Penllyn Manuscript of Ancient Harp Music. Llangefni.

Ellis, Osian 1977. Ap Huw: Untying the Knot, Soundings, Vol. 6: 67-80. Cardiff.

Ellis, Osian 1980. Hanes y Delyn yng Nghymru/History of the Harp in Wales. Cardiff.

Ellis, Osian 1991. The Story of Harp in Wales. University of Wales Press 1976/1987.

\footnotetext{
${ }^{54}$ Hyvänä (tai paremminkin pahana) esimerkkinä käykööt ne barokkimusiikin editiot, joissa basso continuo -osuudet on valmiiksi realisoitu.
} 
Finnegan, Ruth 1986. The relation between composition and performance; three alternative modes. Teoksessa The Oral and Literate in Music, toim Tokumaru ja Yamaguti, s. 73-85: Tokio.

Jones, Edward 1986. Musical and Poetical Relicks of the Welsh Bards, 1784. faksimilepainos, Robert Morley \& Co Ltd: Lontoo.

Ling, Jan 1989. Europas musikhistoria - 1730. Esselte Studium, Göteborg, (1966).

Nettl, Bruno 1982. Types of Tradition and Transmission. Julkaisussa The Garland Library of Readings in Ethnomusicology, vol: 297-315, ed. Kay Kaufman Shelemay. Musical Processes, Resources and Technologies, Garland Publishing, New York \& London. Alunperin julkaistu: Cross-Cultural Perspectives in Music, eds. Robert Falck and Timothy Rice, Toronto; University of Toronto Press, 3-19).

O'Sullivan, Donal 1983. Carolan, the Life, Times and Music of an Irish Harper, vols I \& II. Celtic Music. Louth.

Page, Christopher 1987. Voices \& Instruments of the Middle Ages. J. M. Dent \& Sons Ltd: Lontoo.

Pekkilä, Erkki 1986. Ideal patterns in the Finnish juoksuvalssi: a paradigmatic segment analysis. Artikkeli teoksessa The Oral and the Literate in Music.

Polin, Claire 1979. Observations on the Ap Huw Manuscript, Music and Letters, Vol. 60, No. 3: 296-304. Lontoo.

Polin, Claire 1982. The Ap Huw Manuscript. The Institute of Mediaeval Music-Musicological Studies, Vol. XXXIV. Henryville.

Rimmer, Joan 1986. Edward Jones's Musical and Poetical Relicks of the Welsh Bards, 1784: a re-assesment. The Galpin Society Journal, Vol. XXXIX: 77-96. Lontoo.

Rimmer, Joan 1963. James Talbot's Manuscript. The Galpin Society Journal, Vol. XVI: 63-73. Lontoo.

Rimmer, Joan 1987. Patronage, Style and Structure in the Music attributed to Turlough O'Carolan. Early Music,Vol II/1987: 164-174. Oxford University Press: Lontoo.

Roberts, Enid 1982. Marwnadau Telynorion Traf. Hanes Sir Ddinbych 1966 ac ail-gyhoeddwyd yn Cerd a Chân. Dinbych.

Thomas Gwyn 1968. The Caerwys Eisteddfodau. Gwasg Prifysgol Cymru, Caerdydd.

Thomas, Wyn, (toim.) 1987. Llawysgrif Robert ap Huw, faksimilepainos, Gregg International: Godstone.

Tokumaru Y. \& Yamaguti O. (ed.) 1986. The Oral and the Literate in Music, Academia Music: Tokio.

Treitler, Leo 1974. Homer and Gregory. The Transmission of Epic Poetry and Plainchant. Musical Quarterly, LX: 333-372.

Treitler, Leo 1986. Orality and literacy in the music of the European Middle Ages. Artikkeli teoksessa The Oral and the Literate in Music, Academia 
Music, Tokio; toim. Tokumaru ja Yamaguti.

Whittaker, Paul D. 1974. British Museum Additional Manuscript 14905; an interpretation and re-examination of the music and text. M.A. Dissertation, University of Wales.

William, Dafydd Wyn 1974. Robert ap Huw, y Telynor o Fodwigan. Welsh Music, vol. IV no. 7: 23-30. Dinbych.

\section{Painamattomat lähteet}

Crossley-Holland, Peter 1995. The composers in the ap Huw Manuscript: the evidence for their date and indentity. Toistaiseksi julkaisematon artikkeli; julkaistaan v. 1997 sarjassa The Advanced Welsh Music Studies.

Evans, Robert 1995. Towards the unified tuning cycle. Esitelmä Bangorissa v. 1995 järjestetyssä ap Huw -symposiumissa. Toistaiseksi julkaisematon.

Powell, Nia 1995. Robert ap Huw - the wanton minstrel of Anglesey. Toistaiseksi julkaisematon artikkeli, julkaistaan vuonna 1997 sarjassa The Advanced Welsh Music Studies.

Rees, Stephen P 1995. Aspects of the paleaography and history of the ap Huw MS. Toistaiseksi julkaisematon artikkeli, julkaistaan vuoden 1997 sarjassa The Advanced Welsh Music Studies.

Toivanen, Pekka 1995. Robert ap Huw Manuscript: Problems of transforming music into written text and written text into music. Toistaiseksi julkaisematon artikkeli, julkaistaan vuonna 1997 sarjassa The Advanced Welsh Music Studies.

Whittaker, Paul D 1995. The Tablature of Iolo Morgannwg, Lbl Add. MS 14970. Toistaiseksi julkaisematon artikkeli, julkaistaan vuonna 1997 sarjassa The Advanced Welsh Music Studies.

\section{Käsikirjoituslähteet}

BM Add. MS 14 905. British Library, Lontoo.

Panton MS 56. National Library of Wales, Aberystwyth.

Peniarth MSS 60, 64, 194. National Library of Wales, Aberystwyth.

Havod MS 3. University Library, Cardiff.

\section{Haastattelut}

Robin Huw Bowenin haastattelu ja videointi. Tammikuu 1995, Aberystwyth. Robert Evansin haastattelu ja videointi. Tammikuu 1995, Cardiff. 